\title{
Teenage Dating Violence: The Need for Expanded Awareness and Legislation
}

\author{
Kathryn E. Suarez†
}

Intimate violence among teenagers is a social problem of epidemic proportion that has remained largely unrecognized by the domestic violence movement and by lawmakers. If such abuse continues to be ignored by society, a whole new generation's acts of violence will be cultivated and condoned, leading to societal attitudes that facilitate and tolerate all forms of domestic violence. In this Comment, the author highlights the urgency of eradicating such societal attitudes and argues that, at a minimum, the same legal protections now available to adult victims should be made available to teenagers. At present, most domestic violence statutes exclude minors, either by a requirement of cohabitation or marriage, or by an explicit requirement of adulthood. The author proposes that each state expand the coverage of its civil and penal domestic violence statutes to include teenagers in dating relationships.

\section{INTRODUCTION}

The first time it happened, I was about fourteen and my boyfriend was sixteen. He saw me hug my brother in the hall at school, but he didn't know it was my brother 'cause we'd just started dating. He drug me out of school, behind a store and just beat me up-literally. He said if anyone asked me what happened, to tell 'em I got imto a fight with someone; not to dare tell anyone he hit me. ${ }^{1}$

$$
\text { -Eleventh-grade girl }
$$

Intimate violence among teenagers is a social problem of epidemic proportion that has remained largely unrecognized by the domestic violence movement and by lawmakers. ${ }^{2}$ The domestic violence movement originally

Copyright $\odot 1994$ California Law Review, Inc.

† B.A. 1990, University of California, Berkeley; J.D. candidate 1994, Boalt Hall School of Law, University of California, Berkeley. Special thanks to Sarah Wilson, Christine Suh, and Nancy Lemon for their contributions to the preparation of this Comment.

1. Denise Gamache, Domination and Control: The Social Context of Dating Violence (quoting an anonymous eleventh-grade girl), in Dating VIolence: Young Women IN DANGer 69, 69 (Bartie Levy ed., 1991).

2. "Teenagers" are defined for purposes of this Comment as young people between the ages of 13 and 17, since 18- and 19-year-olds are considered legal adults. 
set out to expose, both to lawmakers and to society at large, the epidemic of marital abuse. In doing so, researchers noted that domestic violence is a phenomenon that cuts across all socioeconomic and racial lines. ${ }^{3}$ However, the domestic violence movement and the law will do little to reduce the incidence of intimate violence until it is acknowledged that such violence is not confined to adults.

Teenagers learn early that the state will rarely prevent or punish abuse. The implications for future behavior are obvious: "Young people who are involved in violent dating relationships express greater acceptance of violence in inarriages . . . . By effectively responding to the abuse of power in adolescent dating, a commumity can influence the nature of adult intimate relationships ...."4

The realization that teens are vulnerable to violent abuse thus highlights the urgency of eradicating societal attitudes that facilitate and tolerate all forms of domestic violence. Teenage intimate violence offers evidence that these attitudes are self-perpetuating. If largely ignored by society and the legal system, a whole new generation's acts of violence will be cultivated and condoned.

To date, the legal systein has not done anything specifically to protect teenage victims of dating violence. At a minimum, the same legal protections that are now available to adult victims should be made available to teenagers. A simple reform, one which this Comment advocates, would be for eacl1 state to expand the coverage of its civil and penal domestic violence statutes to include teenagers in dating relationships. As they presently stand, most domestic violence statutes exclude minors, either by a requirement of cohabitation or marriage, or by an explicit requirement of adulthood. ${ }^{5}$

This Comment will explore the incidence and sociocultural context of teen dating violence and address the legal issues involved. While there is disagreement over whether teen battering is precisely analogous, psychologically and socially, to adult battering, there is a consensus that it is just as prevalent. ${ }^{6}$ Similarly, there is no dispute among researchers that the law must confront this problem. ${ }^{7}$

Throughout the Comment, I assume the abuser is male and the abused is female. This is not to say that male abuse by females, or even homosexual battering, should be treated any differently. Nevertheless, although

3. See Kathleen Waits, The Criminal Justice System's Response to Battering: Understanding the Problem, Forging the Solutions, 60 WASH. L. REv. 267, 276 (1985).

4. Gamache, supra note 1 , at $82-83$.

5. See infra text accompanying notes 79-101.

6. See Sheila J. Kuehl, Legal Remedies for Teen Dating Violence, in DATING Violence: Young WOMEN IN DANGER, supra note 1, at 209, 209.

7. See, e.g., id. at 220 ("Legislative change is needed throughout the United States to create legal options now lacking for young victims of relationship violence."); Gamache, supra note 1, at 80-83 (suggesting intervention strategies that include legal sanctions). 
male teenagers may sometimes be the victims of dating violence, teenage females are more likely to sustain serious injury from dating violence than are teenage males. ${ }^{8}$ Furthermore, the cultural and social context that enables battering stems from a patriarchal hierarchy of domination and control that systematically makes young women more susceptible to abuse. ${ }^{9}$ Since the most effective legal response will need to combat such systemic domination, the archetypal scenario of male abuser and female victim will be the focus of this Comment.

In Part I of this Comment, I will explore the prevalence and characteristics of teen dating violence. In Part II, teen dating violence will be analogized to adult battering statistically, characteristically, and theoretically. Many commentators beheve that teen dating violence stems from the same social and interpersonal dynamics that foster adult intimate abuse. ${ }^{10}$ Furthermore, the patterns of abusive behavior in the teenage dating scenario tend to mirror the patterns of abuse prevalent in marital settings. This analogy is crucial to my thesis that teen dating violence can be dealt with under current domestic violence laws, despite the special needs of minors.

Part III will survey current domestic violence legislation. It will demonstrate how most domestic violence statutes operate to exclude teenagers from their coverage. It will also highlight the few advances the law has made in including teens. Part IV of this Comment will propose that state domestic violence laws be rewritten to cover teenagers.

In order to buttress my clam that teenagers should be covered by domestic violence legislation, Part V of this Comment will explore the many aspects of domestic violence legislation that teens cannot presently use. Many state legislatures have enacted enlightened changes in domestic violence laws, including criminalization of restraming order violations, mandatory arrest policies, pro-prosecution policies, and victim community service funding. If teens are not covered by domestic violence legislation, they will not reap the benefits of these changes. Finally, because teen dating violence differs from adult abuse im that the abuser and victim are both minors, Part VI will examine special issues raised by the minority status of teenagers.

8. Gamache, supra note 1, at 73.

9. See id. at 70-71.

10. See, e.g., Gamache, supra note 1, at 70-73; Kuehl, supra note 6, at 209; Fern Shen, Welts Betray Dark Side of Teen Dating: Specialists See a Youthful Version of Battered Spouse Syndrome, WASH. Post, July 18, 1993, at A1, A16. 
The Prevalence and Characteristics of Teenage Dating VIOLENCE

\section{A. The Definition of Dating Violence}

As used in this Comment, dating violence is defined as an act, or a threat, of physical abuse in the context of any interaction involved in the courtship or inate selection process. ${ }^{11}$ While psychological abuse is a primary means of controlling others and is an inherent aspect of most abusive relationships, studies of teenage dating violence have traditionally concentrated on physical abuse and injury. ${ }^{12}$

Researchers have not reached a consensus on the precise definition of "dating" or "courtship," concepts which can potentially include a broad range of activities and participants. For purposes of this Comment, dating is defined as "a dyadic interaction that einphasizes mutually rewarding activities that can enhance the likelihood of future interaction, emotional commitunent, and/or physical intimacy."13

\section{B. The Prevalence of Teenage Dating Violence}

It is estimated that approximately twenty-eight percent of dating individuals will be involved in intimate violence at some point during their dating lives. ${ }^{14}$ Estimations of the statistical prevalence of dating violence vary somewhat due to variations in samphing, research designs, and analytical decisions. ${ }^{15}$ In general, though, it is estinated that about one third of all females under the age of twenty have either experienced some kind of dating violence or will experience it before they are adults. ${ }^{16}$

I1. Different definitions of dating violence have been suggested. See David B. Sugarman \& Gerald T. Hotaling, Dating Violence: A Review of Contextual and Risk Factors, in Dating Violence: Youna Women IN DANGer, supra note 1, at 100, 101-03. These definitions generally exclude sexual abuse. See id. at 101-02. This omission does not imply that the two forms of aggression are unrelated. Instead, sexual abuse "is excluded as an attempt to focus narrowly on a single phenomenon to facilitate the research review process." Id. at 102 . Accordingly, this Comment will explicitly exclude date rape from its definition of teenage dating violence.

12. See id. at 101 .

13. Id. at 103 .

14. Id. at 103-04.

15. See David B. Sugarman \& Gerald T. Hotaling, Dating Violence: Prevalence, Context, and Risk Markers, in Violence in Dating Relationships: Emergng Social Issues 3, 5-11 (Maureen A. Pirog-Good \& Jan E. Stets eds., 1989). For a comparison of the somewhat divergent results of sevcral studies that have surveyed college or high school students, see id. at 7, tbl. 1.1. Interestingly, college samples produce higher average prevalence rates $(31.9 \%)$ than do samples of high school students (22.3\%). Id. at 6.

16. Kuehl, supra note 6, at 209; see also Sugarman \& Hotaling, supra note 15 , at 6 (stating that the mean prevalence rate in studies of dating violence published between 1985 and 1987 is $31.2 \%$ ). 


\section{The Social Context of Teenage Dating Violence}

In order to comprehend the prevalence of teen dating violence, the social context in which it occurs must be explored. Dating can serve as an important role in the developmental process as it "functions to allow rehearsal of the roles teens expect to assume in adult relationships."17 Yet, when teenagers first begin exploring their sexuality through relations with the opposite sex, they inay conforn to extreme and stereotypical gender roles. Teen dating relationships may, therefore, be characterized by exaggerated role playing, in which the male assumes the dominant role, and the female relegates herself to a position of submissiveness. ${ }^{18}$ Because of the sexisin inherent in this role playing, teen dating provides an environment ripe for abuse. ${ }^{19}$

One college freshman's account of abuse highlights this context of domination and control: "Lots of times he told me I deserved it. Most of the time he said that I deserved to be treated that way because I was such a whore, such a bitch and stuff. So he almost gloated. It made him feel really powerful. I started feeling real inadequate."20

Peers expect a "boyfriend" to be sexually aggressive in, domineering in, and controlling of all aspects of the relationship. ${ }^{21}$ Males inflict violence to demonstrate their masculinity. ${ }^{22}$ On the other hand, girlfriends are expected to be the caretakers, responsible for the success of the relationship and dependent upon the boyfriend for social acceptance and self-esteem. ${ }^{23}$

Adolescents will go to great lengths to avoid being labeled different. "For example, fearing the stigina of homosexuality, adolescents may behave in ways that seem exaggerated to prove their heterosexuality. Or, feeling pressure to prove that they are not 'too attached' to their families may lead them to behave like exaggerated adult males and females." 24 The social demands of adolescence, including conformity, render teens susceptible to battering. Spurred by an intense fear of not fitting in, adolescents conform to peer norins; such norms often "require" that a young woman have a boyfriend. ${ }^{25}$

17. Gamache, supra note 1 , at 73.

18. Barrie Levy, Introduction to Dateng Violence: Young Women in DaNGer, supra note 1, at 3, 4-5.

19. Id. at 5 .

20. Gamache, supra note 1 , at 75 (quoting an anonymous college freshman).

21. Levy, supra note 18 , at 5 .

22. See Peter J. Burke et al., Gender Identity, Self-Esteem, and Physical and Sexual Abuse in Dating Relationships (recognizing that the prevalent theory is that males inflict violence to demonstrate masculinity but concluding that a more feminine identity is associated with both sustaining and inflicting abuse), in Violence in Dating Relationships: Emerging Social Issues, supra note 15 , at $72,73,88$.

23. Levy, supra note 18 , at $4-5$.

24. Id. at 4.

25. Id. 
Moreover, boyfriends often expect and demand that they be made the top priority in the girlfriend's life and that the girlfriend forgo activities she would otherwise pursue. As one college freshman recounts:

At first it was pretty normal, nonchalant. The more I saw hiin, the more he decided he wanted these real strict things. I couldn't look at anybody; I couldn't talk to anybody, go out anyplace without him. I couldn't do anything unless it was with him or unless he knew about it. ${ }^{26}$

Moreover, teenage girls often date older boys, which heightens the power inequities. 27

Because adolescents are inexperienced in relationships, they may not be able to handle the intense feelings and may not possess the inaturity to deal with the complex problems that arise in relationships. ${ }^{28}$ Also, since the girlfriend equates her best interest with that of the relationship, her selfesteem and identity often become inextricably linked with the success of the relationship: "A teen's identity is everything, and a lot of girls get their identity from dating. She's dating Bubba, and there are eight girls waiting to do the same. She tries to justify his behavior. She assumes the blane."29

Furthermore, a young woman who directs all of her attention to her boyfriend is likely to be isolated from both her friends and her family. In part, the exclusive nature of this type of relationship may cause the girlfriend to cut herself off froin family and friends. In many instances, though, a young woman will devote all of her attention to a relationship in order to seek refuge froin family problems and/or neglect. Teenagers often experience a lack of security and fulfillment in their family relations, and romantic relationships often operate to fill this gap. As a result, teenage girls may have inore contact and closeness with their boyfriends than with their own family meinbers. ${ }^{30}$

This isolation is exacerbated by the adolescent's continual struggle for independence from her parents. As a result, the young woman may be unable or unwilling to ask for help from her family even if she senses the relationship has taken an abusive turn. An eleventh-grade girl explains: "You work so hard to get your independence. One thing like that could just blow it all, and you'd have to start all over again. If you just leave it and

26. Gamache, supra note 1 , at 79 (quoting an anonymous college freshman).

27. Id. at 73-74.

28. Levy, supra note 18 , at 5 .

29. Kathy Swindle, Beginnings of Abuse: When Boys Strike Their Girlfriends, It's an Early Sign of Big Trouble, SACRAMENTO BeE, June 5, 1992, at Scene 7 (quoting Jan Langbein, Executive Director, Genesis Women's Shelter, Dallas, Texas).

30. See Judy Chicurel, He Loves Me Not: A Rise in High School Dating Violence Has Some Teenagers Asking: What is Love, NewsDAy, Mar. 12, 1992, at 64 ("Kids are more paired off today ... . Maybe because many of them are latchkey children they perceive a lack of sccurity in their lives and look toward a relationship for that fulfillment. Some of these girls see their boyfriends more than they see members of their own families." (quoting Christine Szumigala, a health teacher at Hicksville High School, New York)). 
don't tell your parents, you still have your independence."31 Unable to turn to her family, the girlfriend may be denied much needed guidance in assessing whether or not a problem exists. What makes the situation worse is that the teenager may have trouble identifying an abusive relationship on her own.

One reason that a teen nray not see her relationship as abusive is that she may interpret the violence as a sign of jealousy and then misinterpret this jealousy as a sign of love. Unfamiliar with norms of sexuality and intimacy, teens are likely to experience "normative confusion."32 In other words, teenage girls are likely to view the jealousy and possessiveness that spur the abuse as signs of love. Violence then is seen by soine teens as a normal way to express love. ${ }^{33}$

Only when the abuse escalates to the point of severe physical injury is the girlfriend likely to recognize a problem. However, even then the girlfriend may not perceive the violence as a problein in itself but may attribute it to some other difficulty in the relationship. ${ }^{34}$ If only those other problenis would go away, the teen rationalizes, then so would the abuse. ${ }^{35}$ However, even a teen who recognizes a problem is unlikely to seek help. It is estimated that only one in every twenty-five teenagers involved in an abusive relationship will seek help. ${ }^{36}$ She inay be enrbarrassed or inay lack education concerming legal options and community programs. Or, she may have learned what many other abused teens have learned: parents, teachers, and law enforcement officials do not always take adolescents seriously. "They are just kids," "she's overreacting," or "just find a new boyfriend" are typical responses. ${ }^{37}$

II

\section{The Comparison Between Adult and Teenage Abuse}

\section{A. The Similarities}

In general, violent teen relationships have a great deal in common with adult battering situations. Teen dating violence, like adult battering, is not confined to one particular socioeconomic class, ethnic group, or community. ${ }^{38}$ The same social context fosters both teenage and adult intimate vio-

31. Gamache, supra note 1, at 80 (quoting an anonymous eleventh-grade girl).

32. Sugarman \& Hotaling, supra note 15 , at 13.

33. Shari Roan, Abused Women May Be "Hostages," L.A. Tames, Aug. 20, 1991, at E1, E5 (citing a study in which $25 \%-35 \%$ of young women perceived violence used against them by their boyfriends as a sign of love).

34. Levy, supra note 18 , at 9.

35. Id.

36. Roan, supra note 33, at E5.

37. See Levy, supra note 18 , at 5 (providing examples of the ways iu which adults do not take adolescents seriously).

38. See Robin Abcarian, Jenny's Story: Parents Were the Last to Know, L.A. Tmes, Oct. 13, 1991, at E14 ("Dating violence can happen to any adolescent, anywhere."). 
lence: "Violence in dating relationships and marriages is reinforced by cultural norms that support the need for a hierarchy of power in human relationships." ${ }^{39}$ Furthermore, when questioned in climical studies, many adult victims of intimate abuse indicate that their first experience with intimate violence occurred while they were still in their teens. ${ }^{40}$

Moreover, teenage dating violence appears to be as prevalent as marital abuse: "On average, over one-third of those surveyed report an experience of violence victimization at some point in their dating history. This proportion is ... similar to the lifetime prevalence rate that has been reported in studies of spousal violence." 41

The dynamics of the two types of intimate violence are also quite similar. Specialists say that "abusive dating relationships ... are nearly identical to adult battered spouse syndrome, down to the victim's low self-esteem and the batterer's need to assert power ...."42 This similarity in dynamics nay have to do with the similar gender-role expectations that lie behind both types of violence:

The violence [in teen relationships] often is imitiated when the couple involved perceives that they have entered into an exclusive, marriage-like relationship. This shift in status seems to elicit expectations tied to gender, including the male's right to control his partner and the female's obligation to yield to his wishes. . . . [A]dolescent batterers express similar beliefs in their right to control female partners and employ tactics similar to adult batterers to maintain this position. ${ }^{43}$

Additionally, jealousy, control, threats, physical violence, and sexual violence are integral to both teen and adult abusive relationships. Teenage abusers, like adult abusers, use intimidation, make frightening gestures, smash objects, drive dangerously, and kidnap or harm pets to obtain compliance from the viction. ${ }^{44}$ Those committing dating violence, however, are more likely to use objects or criminal weapons during the abuse than those involved in marital violence. 45

As in adult relationships, psychological abuse in teen relationships dimmishes the victim's independence and destroys her self-esteem so that she feels she has no other option than to remain in the relationship. The psychological effects of teenage abuse are just as severe as the physical injuries and need to be taken as seriously, especially since they occur during the young woman's formative years.

\footnotetext{
39. Gamache, supra note 1, at 71 .

40. Nona K. O'Keeffe et al., Teen Dating Violence, 31 Soc. WorK 465, 468 (1986).

41. Sugarman \& Hotaling, supra note 15 , at 8.

42. Shen, supra note 10 , at A16.

43. Gamache, supra note 1, at 73 .

44. Id. at 77 .

45. Sugarman \& Hotaling, supra note 15 , at 24 .
} 
Just like the adult woman, an abused teen may be terrified to leave the relationship, believing the threats and knowing that the batterer is capable of revenge. Analogous to battered women, teenage girls are at the greatest risk of plysical mjury when they try to leave the relationship. ${ }^{46}$ Abused teens, like adult women, fear for their safety as their attempts to leave their abuser result im more imtense battering. As one teen victim recalls: "After a while, when it starts getting worse, you get scared to leave him. I'd tell my boyfriend I didn't want to go out with him anymore, and it would get worse. He'd start slapping me and say ' $I$ ' in not gonna quit till you tell me you're not leaving.' "'47

\section{B. The Differences}

While marital violence has long been a reality, ${ }^{48}$ adolescent dating violence is a relatively recent phenomenon because adolescent dating is a relatively recent practice. Prior to World War I, interactions between unmarried young men and women were chaperoned by the family or the community. ${ }^{49}$ "Educators and youth counselors say they're seeing more 'dating violence' than ever before, as teens become sexually active earlier in life and images of sexism and violence saturate our culture."50

Unlike most married women, the abused girl in a teen dating relationship does not live under the same roof as her batterer. Moreover, an abused girlfriend, unlike many married woinen, is rarely financially dependent on her abuser.

Because marriage provides the batterer with proximity to, and often economic control over, the abused wife, it may be difficult for some to conceptualize how teenage victims may feel equally trapped $\mathrm{m}$ an abusive relationship. Of course, one of the main reasons is that the teenage abuser's threats of revenge are just as frightening and just as legitimate as in the adult battering context. ${ }^{51}$ Additionally, while teen victims are often not financially dependent on their abusers, they are almost always emotionally and socially dependent on them. ${ }^{52}$ Also, many of the theories used to explam intimate violence in general and to answer the specific question of

46. Bella English, Where Bruises Don't Belong, Boston Globe, Dec. 7, 1992, at 15.

47. Gamache, supra note 1 , at 70 (quoting an anonymous eleventh-grade girl).

48. See Developments in the Law-Legal Responses to Domestic Violence, 106 Harv. L. Rev. 1498, 1502 (1993) [hereinafter Developments in the Law]. Marital violence has a long history, but it has not always been a crime. Id. ("In fact, United States law condoned wife abuse and protected the right of men to beat their wives through the mid-nineteenth century.").

49. David S. Riggs \& K. Daniel O'Leary, A Theoretical Model of Courtship Aggression, in Violence in Dating Relationships: Emerging Social Issues, supra note 15, at 53, 53.

50. Kurt Chandler, Young Love's Dark Side: Schools Seek to Counter Abuse, Star TrIB. (Mpls.I St. Paul), Nov. 18, 1991, at 1A.

51. See supra text accompanying notes $44-47$.

52. See supra text accompanying notes 29-30. 
why the woman "does not just leave" are equally applicable to adolescents. ${ }^{53}$ These theories are discussed in detail in the following Section.

There are also factors specific to adolescent development that may contribute to the abused teenage woman's vulnerability. ${ }^{54}$ Peer pressure, rigid conformation to female gender role expectations, and lack of dating experience may all contribute to a young woman's reluctance to leave an abusive relationship. ${ }^{55}$

\section{Theories of Intimate Violence}

A number of theories have been suggested to explain the psychological underpinnings of intimate violence. Some, like Lenore Walker's theory, discuss only adult abuse explicitly. Others, like James Makepeace's, specifically address dating violence. All lielp clarify the dynamics of the teenage dating violence scenario.

\section{Lenore Walker's Theory of the Battered Woman}

Lenore Walker posits that the battered woman remains in the relationship due to "learned helplessness,"56 a downward spiral in which the repeated batterings, as well as the woman's failed attempts at leaving the relationship, reduce the woman's self-esteem to such an extent that she becomes powerless. ${ }^{57}$ It is possible that the dynamics of a teenage abusive relationship are quite similar to the adult battering scenario, ${ }^{58}$ which Walker has discovered plays itself out via a cycle of violence, including a tensionbuilding stage, a battering stage, and a loving reconciliation stage.

In phase one, the "tension building phase," minor battering incidents may occur, but the victim tries to become nurturing and to calm the abuser: "[S]he beheves that what she does will prevent his anger from escalating. If sle does her job well, then the incident will be over; if he explodes, then she assumes the guilt. In essence, she has become his accomplice by accepting some of the responsibility for his abusive behavior." 59

53. Of course, while it is common for critics to ask why the victim does not escape an abusive situation, the more appropriate question in both the teen and the adult context is why the abuser does not stop beating the abused.

54. Gamache, supra note 1 , at 74 .

55. Id.

56. Lenore E. Walker, The Battered Woman 43 (1979).

57. Id. at 55 .

58. Before it can be ascertained whether the theoretical analysis of spousal violence is applicable in the dating violence context, further research must be done. While the social and psychological factors which foster marital abuse may be the same ones that account for dating violence, certain commentators, including James Makepeace, believe that there are fundamental differences between the two and that dating violence is not simply spousal abuse without the legality of marriage. See James Makepeace, Dating, Living Together, and Courtship Violence, in VIOLENCE IN DATING Relationships: EMERGino Social. Issues, supra note 15, at 94, 106.

59. WALKER, supra note 56 , at 56. 
Phase two is characterized by the discharge of tensions that have accumulated during the initial phase, resulting in an acute battering. ${ }^{60}$ Occasionally the woman will provoke the batterer into a phase-two incident because she anticipates the explosion and wants to get it over with. ${ }^{61}$

In the third phase, the batterer knows that he has gone too far, begs her for forgiveness, and then promises to change his ways. At this point, he becomes very kind and affectionate, persuading the woman not to take legal action. ${ }^{62}$ Many women then stay as they "see themselves as the bridge to their men's emotional well-being."

\section{The Stockholm Syndrome}

Another theory, proposed by Graham and Rawlings, argues that the bonding which takes place between abusive partners is a survival mechanism, analogous to the dynamic that occurs between hostages and captors. ${ }^{64}$ While other researchers argue that there are a complex combination of factors (such as gender role expectations, adolescent pressures, and a need to become independent from the family) that keep a young woman in a relationship that is physically, sexually, or emotionally abusive, ${ }^{65}$ Graham and Rawlings posit that factors affecting whether a woman (young or old) stays in an abusive relationship are determined by "the situation to which she is exposed while in the relationship." $" 66$

The notion that hostages, as a survival mechanism, will bond with their captors has been dubbed the "Stockholm Syndrome." This title refers to a 1973 bank holdup in Stockholm, Sweden that resulted in four hostages bonding bidirectionally with their captors after being held hostage for six days. "The hostages even came to see their captors as protecting them from the police[.]"67 The kidnappers claimed they had become too fond of the captives to kill them, even though killing them would have facilitated police negotiations. ${ }^{68}$ Following the release, a hostage reportedly even became engaged to one of the captors. ${ }^{69}$

60. Id. at 59.
61. Id. at $59-60$.
62. Id. at 65.
63. Id. at 68 .
64. Dee L.R. Graham \& Edna I. Rawlings, Bonding with Abusive Dating Partners: Dynamics of

64. Dee L.R. Graham \& Edna I. Rawlings, Bonding with Abusive Dating Partners: Dynamics of
ckholm Syndrome, in DAting Violence: Young WOMEN IN DANGer, supra note 1 , at $119,120$.

65. Id. at 119.

66. Id.; see also Robin Abcarian, In Love, In Danger: Teen Victims of Dating Abuse Often Are Too Immature and Insecure to Escape Jealous, Sometimes Violent Boyfriends, L.A. TIMEs, Oct. 13, 1991, at E1, E14 ("All it really takes for a woman-for anybody-to be a victim . . . is for somebody to be willing to victimize thein." (quoting Barrie Levy, therapist and founder of the Southern California Coalition for Battered Women)).

67. Graham \& Rawlings, supra note 64 , at 120 .

68. Id.

69. Id. 
According to this theory, the victim of intimate violence tolerates the psychological abuse because she sees herself through the abuser and has a dismcentive to leave because she defines herself through him. ${ }^{70}$ Moreover, she is afraid to show disloyalty to him because he threatens her survival; even when let free, she fears he will get her again. ${ }^{71}$ She feels responsible because it is her duty to protect him; this is the only sense of control she has in an otherwise powerless and overwhelming situation. ${ }^{72}$

The dynamics of this theory are especially important in the context of teen abuse. The Stockholm Syndrome reconfirms that women of all ages are susceptible to the entrapment of abuse and that the dynamics of battering have little to do with age. In fact, experts believe that the syndrome may be more likely to develop in a young woman's dating relationship, in part because young women are more likely to perceive violence as evidence of love. ${ }^{73}$

\section{James Makepeace's Theory of Dating Violence}

James Makepeace has proposed a theory of dating violence that focuses less on drawing similarities to marital battering situations and mstead concentrates on understanding dating violence in terms of the stages of courtship. ${ }^{74} \mathrm{He}$ theorizes that courtship violence is not analogous to marital violence and instead las its own dynamic. Makepeace explains:

Courtship violence is not just spousal abuse before marriage. It is a distinct phenomenon with dynamics that can only be understood in terms of the issues and stages of courtship itself. There may be two fundamental types of courtship violence: a particularly brutal and often sexually motivated type, which is more prevalent in very early stage relationships, and a second type, which derives from the working out of relationship difficulties such as jealousy and rejection, and which becomes more injurious in the later stages of courtship, when the imvestinent in the relationship is greater. ${ }^{75}$

The difference Makepeace observes between dating and marital violence may have inportant implications for therapy, but it provides no theoretical basis for contending that the legal system ought to treat the problems as fundamentally different. According to Makepeace, the most unique policy implication that arises from the difference between courting and marital violence is the need for the educational system to step in and for administrators, teachers, and counselors to recognize and deal with the problem. ${ }^{76}$

70. Id. at 122 .

71. Id. at $122-23$.

72. Id.

73. Some Accept Violence in Dating Game, OrLando Sentinel, Aug. 30, 1991, at E5 (discussing the 1991 American Psychological Association's annual meeting).

74. Makepeace, supra note 58, at 106.

75. Id.

76. Id. at 105-06. 
III

\section{The Discrepancies IN Legal Remedy}

While the dynamics of teen and adult intimate violence are quite similar, the protections provided by the law for these two classes of abuse are dramatically different. Most domestic violence laws explicitly or effectively define domestic violence as abuse against adults, and hence, do not provide protection for teen victims. These definitions are im part the result of an attempt to differentiate domestic abuse from actions involving child abuse. ${ }^{77}$ However, failure to combat teenage violence under the rubric of domestic violence legislation also refiects a societal unwillingness to acknowledge the problem and address it in a meaningful way.

Apart from the symbolic importance that is lost by not recognizing teen abuse as another prong of domestic violence, the failure to define teen dating violence as domestic violence may have important legal implications. The domestic violence movement continually pushes for statutory reforms, such as mandatory arrest policies in domestic violence situations, universal criminalization of domestic violence restraining order violations, and inore stringent penalties for batterers. ${ }^{78}$ If teenagers are legally excluded from the definition of domestic violence victims, they may be unable to benefit from the hard-fought legal victories of the domestic violence movement.

\section{A. Teenagers Are Excluded from Most Domestic Violence Statutes}

Most domestic violence statutes begin by defining domestic violence as abuse "between family or household members," and then provide a more specific definition of what constitutes a family or household member. ${ }^{79}$ The limiting construction of the phrase "family or household member" is what typically operates to exclude teens from the statute's protection. In thirty-nine states (all but Alaska, California, Colorado, Illinois, Massachusetts, New Hampshire, New Mexico, North Dakota, Pennsylvania, Washington, and West Virginia) ${ }^{80}$ and in the District of Columbia, ${ }^{81}$ teens involved in dating violence are not considered victims of domestic violence. Unless they have parented a child together or have lived together, dating teens are not covered by these forty domestic violence statutes and their corresponding legislative enactments. ${ }^{82}$ Even teens who are coparents or who were or are cohabitants are denied relief in twelve states

77. Kuehl, supra note 6, at 212.

78. See infra Part V.

79. See, e.g., Conn. Gen. Stat. Ann. § 46b-38(a) (West Supp. 1993); Haw. Rev. Stat. § 586-1

(Supp. 1992).

80. See infra text accompanying note 104 .

81. See infra text accompanying notes 88-90.

82. See infra text accompanying notes 84-101. 
because these statutes specifically require majority status or emancipation. ${ }^{83}$ These types of definitions work to deny teens, the majority of whom are not living with their boyfriends or are not the mother of their boyfriend's child, protection under domestic violence statutes.

Statutes that operate to exclude adolescent dating relationships from their coverage can be categorized according to their definitions of domestic violence. They fall into four categories: (1) statutes that define the victim as a spouse/former spouse, cohabitant/former cohabitant, or coparent; (2) statutes that defme the victim as a spouse/former spouse, cohabitant/former cohabitant; (3) statutes with a strict requirement that the victim and abuser currently reside together; (4) statutes with some type of specific "adult" requirement. A fifth category is comprised of those statutes that do not operate to exclude teenagers from their coverage.

\section{Statutes That Define the Victim as a Spouse/Former Spouse, Cohabitant/Former Cohabitant, or Coparent}

Sixteen states, as well as the District of Columbia, define a domestic violence victim as a spouse, former spouse, cohabitant, former cohabitant, or coparent. ${ }^{84}$ While the actual wording of the statutes varies, their scope of protection is functionally the same. Florida, for example, defines "family or houseliold" member as

spouses, former spouses, persons related by blood or marriage, persons who are presently residing together, as if a family, or who have resided together in the past, as if a family, and persons who have a child in common regardless of whether they have been married or have resided together at any time. ${ }^{85}$

A typical statute, the domestic violence code in Kentucky, defines domestic violence as abuse between "family members or members of an unmarried couple." 86 However, a member of an unmarried couple "means eacli member of an unmarried couple which allegedly has a child in common, any children of that couple, or a member of an unmarried couple who are living together or have formerly lived together."

83. See infra text accompanying notes 98-101.

84. Ala. Code § 15-10-3(a)(8) (Supp. 1993); Ariz. Rev. Stat. Ann. § 13-3601(A) (Supp. 1993); Conn. Gen. Stat. AnN. § 46b-38a(1)-(2) (West Supp. 1993); D.C. Code ANN. § 16-1001(5) (1989 \& Supp. 1993); Fla. Stat. Ann. § 741.30(1)(b) (West Supp. 1993); Ga. Code ANn. § 19-13-1 (Harrison Supp. 1993); IDaho Code § 39-6303(2) (1993); Ky. Rev. Stat. AnN. § 403.720(1), (3) (Michie/BobbsMerrill Supp. 1992); Me. Rev. Stat. AnN. tit. 19, § 762(4) (West Supp. 1992); MinN. Stat. AnN. § 518B.01 subd. 2 (West Supp. 1993); Neb. Rev. Stat. § 42-903(1), (5) (Supp. 1992); Nev. Rev. Stat. ANN. § 33.018 (Michie 1986); OhIo Rev. CODE ANN. § 2919.25 (Anderson 1993); OKLA. STAT. ANN. tit. 22, § 60.1(1), (4) (West 1992); S.D. Codified LAws ANn. \& 25-10-1(1)-(2) (1992); VA. Code. ANN. $\S 16.1-228$ (Michie Supp. 1993) (limiting former cohabitants to those who lived in the same residence at some point during the previous 12 months); WYo. STAT. § 35-21-102(a)(iii)-(iv) (Supp. 1993).

85. Fla. Stat. ANN. $\S 741.30(1)$ (b) (West Supp. 1993).

86. Ky. Rev. Stat. ANN. § 403.720(1) (Michie/Bobbs-Merrill Supp. 1992).

87. Id. § 403.720(3). 
The District of Columbia refers to domestic abuse as an "intrafamily offense" and defines "family meinber" as "a person: (A) to whoin the offender is related by blood, legal custody, marriage, having a child in common, or with whom the offender shares or has shared a inutual residence; and (B) with whom the offender maintains or inaintained an intimate relationship rendering the application of this chapter appropriate." ${ }^{88}$ The statutory language here is noteworthy as it seems to imply that there are other types of nonmarital intimate relationships that warrant recognition under the statute. Alternatively, the statute could be read as requiring a marital, cohabitant, or coparent relationship in addition to soine sort of intimacy. The semantic ambiguity was addressed in Jackson v. United States, ${ }^{89}$ in which the D.C. Court of Appeals remarked that it is not clear whether a relationship between a man and his girlfriend is close enough to coine within the contemplation of this section. ${ }^{90}$

Obviously, few teens will fall within the scope of these fourteen definitions of domestic violence, and thus, teens will be denied the advantages of the accompanying legislative protection.

\section{Statutes That Define the Victim as a Spouse/Former Spouse, Cohabitant/Former Cohabitant}

The obvious difference between this category, which defines domestic violence victims as spouses, former spouses, cohabitants, or former cohabitants, and the previous one is the exclusion of coparents. In these eight states, teens are only "doinestic violence victims" if they live with, or have lived with, or are married to, or have been married to their abusers. ${ }^{91}$ This definition is more limiting than it nay first appear because, while few adolescents can afford to live together, those teens with their own children are the least financially able to leave their parents' hone. While the previous category certainly did not accommodate all dating teenagers, the "coparent" requirenient was generally independent of a requirement of marriage or cohabitation and at least protected a discrete group-teenage mothers. Statutes with a cohabitation or inarriage requirement, on the other hand, function to protect only a very minor seginent of the teenage dating population.

Examples of the typical language of statutes in this category are Hawaii's and Oregon's. Hawaii defines "[f]amily and household inembers" as "spouses or former spouses, parents, children, persons related by

88. D.C. CODE ANN. § 16-1001(5) (1989 \& Supp. 1993).

89. 357 A.2d 409 (D.C. 1976).

90. Id. at $411 \&$ n.6.

91. ARK. Code Ann. § 9-15-103 (Michie Supp. 1991); Haw. Rev. Stat. § 586-1 (Supp. 1992); KAN. Stat. AnN. \& 60-3102 (Supp. 1992) (requiring that the abuser and victim reside together or formerly resided together and that both have legal access to the residence); Miss. CoDE ANN. § 93-21101(a) (Supp. 1993); N.C. Gen. Stat. § 50B-1(a) (1989); OR. Rev. StaT. § 108.610(3) (1991); S.C. Code Ann. \& 16-25-10 (Law. Co-op. 1985); Vт. Stat. Ann. tit. 15, § 1101 (1989 \& Supp. 1993). 
consanguinity, and persons jonitly residing or formerly residing in the same dwelling unit."92 With different language but similar results, Oregon defines a doniestic violence victin1 as a person "who is related by blood, marriage or intimate cohabitation at the present or has been related at some time in the past ...."93

\section{Statutes with a Strict Requirement That the Victim and Abuser Currently Reside Together}

Three domestic violence statutes are characterized by the very limiting requirenent that there be a current or very recent cohabitation. ${ }^{94}$ Louisiana defines family or household members as "spouses, former spouses, . . . and any person living in the same residence with the defendant as a spouse, whether married or not, if a minor child or children also live in the residence, who are seeking protection under this Part."95 Maryland is slightly nore lenient, defining cohabitant as "a person who has had a sexual relationship with the respondent and resided with the respondent in the home for a period of at least ninety days within one year before the filing of the petition."96

This category is significant because these legislatures seem to have specifically aimed to provide protection only for marriage-type live-in relationships. In other states, the "household" requirenent has been interpreted loosely by courts and has been applied to noncohabitating couples, in light of an articulated legislative intent of broad application. ${ }^{97}$ However, the legislatures in these three states have defined "household" members in a very narrow way so as to include only live-in family nuenibers. In light of this inuplicit legislative intent, it is unlikely that courts in these three states could extend statutory doniestic violence protections to dating couples.

\section{Statutes with Some Type of Specific "Adult" Requirement}

Statutes in twelve states define domestic violence victims specifically as adults. ${ }^{98}$ These defmitions present one of the most insurmountable

92. Haw. Rev. Stat. § 586-1 (Supp. 1992).

93. OR. Rev. Stat. § 108.610(3) (1991).

94. Del. Code AnN. tit. 10, $\S 950(5)$ (1975), tit. 10, $\$ 901(9)$ (Supp. 1992); La. Rev. Stat. AnN. $\S 2132(4)$ (West Supp. 1993); MD. FAM. LAw Code ANN. § 4-501(c) (Supp. 1992).

95. LA. Rev. Stat. ANn. § 2132(4) (West Supp. 1993).

96. MD. FAM. LAw CODE ANN. § 4-501(c) (Supp. 1992).

97. See, e.g., Desiato v. Abbott, 617 A.2d 678, 680 (N.J. Super. Ct. Ch. Div. 1992) (holding that the "stated legislative intent inandates [the] court to liberally construe the remedies available and protect any victim of violence occurring in a "family or family-like setting' ").

98. Ind. Code ANN. $\S 34-4-5.1-1$ (West Supp. 1993); Iowa Code ANN. $\S 236.2(2)$, (4) (West Supp. 1993); Mich. Comp. Laws ANn. § 400.1501(c) (West 1988); Mo. ANN. STat. \$§ 455.010(2), (5), 455.020 (Vernon Supp. 1993); Mont. Code ANN. § 45-5-206(2) (1991); N.J. STat. ANN. § 2C:2519(a), (d) (West Supp. 1993); N.Y. Soc. Serv. Law § 459-a (McKinney 1993); R.I. Gen. Laws § $12-$ 29-2 (Supp. 1992); Tenn. Code Ann. § 36-3-601 (1991); Tex. Hum. Res. Code Ann. \$ 51.002(2) (West Supp. 1993); UTAH Code ANN. § 30-6-1(2) (Supp. 1993); W1s. Stat. ANN. § 968.075 (1) (West 
obstacles to teens seeking protection from abusive minor boyfriends. These statutes typically require that the abuse occurred between persons who are either over the age of eighteen or have been legally emancipated from their parents, by marriage or otherwise. ${ }^{99}$ Some of the statutes seem to have been framed to differentiate between intimate battering and child abuse, but the age requirements miposed work to eliminate adolescent intimates from the statutes' scope.

Michigan, for example, defines "victim" as

a person assaulted by or threatened by assault by his or her spouse or former spouse or an adult person or emancipated minor assaulted by an adult person of the opposite sex with whom the assaulted person cohabits or fornerly cohabited; and in which the victim and assailant are or were involved in a consenting, sexual relationship. ${ }^{100}$

New Jersey similarly requires that the abuse be inflicted by "an adult or emancipated minor" and that the victim be eighteen years or older, emancipated, or a coparent. ${ }^{101}$

Therefore, teenagers between the ages of thirteen and seventeen are effectively excluded from these states' definitions. ${ }^{102}$ This means that a teen abused by her boyfriend may not be able to take advantage of programs orgamized and funded by the state to care for domestic violence victims, including domestic violence shelters and nonresidential programs, which provide referrals, legal and medical assistance, and counseling. Many domestic violence programs will aid only adult battered women, and very few communities have organized centers or outreach programs specifically designed to assist teens in abusive dating relationships. ${ }^{103}$

\section{B. Statutes That Do Not Operate to Exclude Teenagers from Their Coverage}

Only eleven states-Alaska, California, Colorado, Illinois, Massachusetts, New Hampshire, New Mexico, North Dakota, Pennsylvamia, Washington, and West Virginia-have structured their domestic violence laws in a manner that allows abused teens to take advantage of them. ${ }^{104}$ It is important to note that these statutes do not specifically

Supp. 1992). Note that in Michigan, Montana, Rhode Island, and Wisconsin, spouses or former spouses of any age are included.

99. But see N.Y. Soc. SERv. LAw \$ 459-a (McKinney 1993) (applying to persons 16 years and older); UTAh Code ANN. $\$ 30-6-1(2)$ (Supp. 1993) (applying to persons 16 years and older). Nevertheless, the great inajority of teens, who are only dating and are not inarried, are not covered under these statutes.

100. Mich. Comp. Laws AnN. $\$ 400.1501$ (c) (West 1988).

101. N.J. Stat. AnN. \& 2C:25-19(a), (d) (West Supp. 1993).

102. But see supra note 99.

103. See infra text accoinpanying notes 231, 243-55.

104. Alaska Stat. § 25.35.200(4) (1992); Cal. Civ. Proc. Code § 542(b)(1) (West Supp. 1993); Colo. Rev. Stat. § 18-6-800.3(1), (2) (Supp. 1993); ILl. ANN. Stat. ch. 750, para. 60/103(6) (Smith- 
include dating adolescents in their definitions of domestic violence. Rather, these statutes are significant because they do not necessarily exclude teen daters explicitly or effectively from their scope of coverage. In other words, these states do not exclusively attach marital, cohabitation, coparent, or adult requirements. Some statutes specifically include the terms "dating" or "courtship relationship" in the statutory definition. Because none of these eleven statutes was specifically written to address the problein of teenage dating violence per se, the extent to which teenagers are included within the coverage of these statutes is somewhat ambiguous. While these statutes are by no ineans exemplary, they are nevertheless noteworthy in that they do not explicitly operate to deny legal protection to teenage victims of dating violence.

Alaska's Marital and Domestic Relations statute was amended in 1991 to include in the definition of domestic violence victims "a person who is not a spouse or former spouse of the respondent but who previously lived in a spousal relationship with the respondent or is in or has been in a dating, courtship, or engagement relationship with the respondent."105

California's Code of Civil Procedure § 542 defines "domestic violence," in relevant part, as "abuse perpetrated against any of the following: (1) A spouse, fornier spouse, cohabitant, former cohabitant, any other adult person related by consanguinity or affinity within the second degree, or a person with whom the respondent has had a dating or engagement relationship." 106 While this statute does not explicitly include minors, it applies to any "person," not any adult, in a dating relationship. California Penal Code $\S 243$ helps refine the boundaries of "dating relationships." Under $\S 243$, "dating relationship" is defined as "frequent, intimate associations primarily characterized by the expectation of affectional or sexual involvenient independent of fniancial considerations." 107

Colorado's Criminal Code defines donestic violence as "the infliction or threat of infliction of any bodily injury or harmful physical contact or the destruction of property or threat thereof as a inethod of coercion, control, revenge, or punishment upon a person with whom the actor is involved in an intimate relationship." 108 An "imtimate relationship" is defined as "a relationship between spouses, forner spouses, past or present unmarried couples, or persons who are both the parents of a child regardless of whether the persons have been nuarried or have lived together at any

Hurd Supp. 1993); Mass. Gen. Laws Ann. ch. 209A, §§ 1(e), 3(a) (West Supp. 1993); N.H. Rev. Stat. ANN. § 173-B:1(I), (TV) (Supp. 1992); N.M. STAT. ANN. § 40-13-2(D) (amended 1993), available in WESTLAW, ST-ANN-ALL Database; N.D. CENT. CODE § 14-07.1-01(2), (4) (1991); 23 PA. Cons. Stat. ANn. § 6102(a) (Supp. 1992); WASH. Rev. Code ANn. § 26.50.010(2), (3) (West Supp. 1993); W. VA. CODE § 48-2A-2(b) (Supp. 1993).

105. Alaska Stat. $\$ 25.35 .200(4)(1992)$.

106. Cal. Crv. Proc. Code $\S 542(b)(1)$ (West Supp. 1993).

107. Cal. Penal Code § 243(f)(11) (West Supp. 1993).

108. Colo. Rev. Stat. § 18-6-800.3(1) (Supp. 1993). 
time."109 Dating teens could possibly qualify as "past or present unmarried couples." However, what is required in order to be a "couple" is ambiguous.

Illinois includes within the purview of its Domestic Violence Act "persons who have or have had a dating or engagement relationship."110 The Illinois statute also provides guidance regarding the determination of whether a "dating relationship" exists. The statute notes that "neither a casual acquaintanceship nor ordinary fraternization between two individuals in business or social contexts shall be deemed to constitute a dating relationship." 111

In its definition of family or household members, Massachusetts includes persons who "are or have been in a substantive dating or engagement relationship ...."112 However, this broad definition does not automatically imply that teen daters will be protected. The statute requires that the relationship

be adjudged [substantial] by district, probate or Boston inunicipal courts, [by] consideration of the following factors: (1) the length of time of the relationship; (2) the type of relationship; (3) the frequency of interaction between the parties; and (4) if the relationship has been terminated by either person, the length of time elapsed since the termination of the relationship. ${ }^{113}$

Interestingly, the Massachusetts legislature appears to have intended specifically to include adolescent relationships within the scope of the statute's coverage. The Massachusetts code section dealing with remedies specifically provides that the court can order "the defendant to refrain from abusing the plaimtiff, whether the defendant is an adult or minor."114

New Hampshire defines domestic violence as abuse between "family or household members or current or former sexual or intimate partners."115 "Intimate partners," in turn, are "persons currently or formerly involved in a romantic relationship, whether or not such relationship was ever sexually consummated."116 The fact that sexual consummation is not required seems to evidence a legislative intent to apply the protections of the domestic violence statute to dating relationships and to teenagers.

New Mexico's Family Violence Prevention Laws appear to apply to teenage daters. The definition of "household member" does not require cohabitation and includes "person[s] with whom the petitioner has had a

109. Id. § 18-6-800.3(2).

110. In. ANN. Stat. ch. 750, para. 60/103(6) (Smith-Hurd Supp. 1993).

111. Id.

112. Mass. Gen. Laws ANN. ch. 209A, § 1(e) (West Supp. 1993).

113. Id. $\S 1(\mathrm{e})(1)$.

114. Id. §3(a).

115. N.H. Rev. Stat. ANN. § 173-B:1(1) (Supp. 1992).

116. Id. § 173-B:1(IV). 
continuing personal relationship."117 Dating would certainly seem to qualify as a "continuing personal relationship."

Although North Dakota's domestic violence statutes are classified under "Adult Abuse," the statutes themselves do not articulate any explicit majority or emancipation requirement; the definition of "family or household member" includes "persons who are in a dating relationship."118

Pennsylvania's statute does not explicitly include "dating relationships" in its wording. However, the statute does define domestic violence as that occurring between "family or household members, sexual or intimate partners or persons who share biological parenthood."119 In Diehl $v$. Drummond, ${ }^{120}$ a Pennsylvania court held that this statute could apply to minors and seened to suggest, while never directly addressing the issue, that a teen boyfriend could be referred to as an intimate partner.

While Washington's statute does not accommodate all teenage daters, it does apply to "persons sixteen years of age or older with whom a respondent sixteen years of age or older has or has had a dating relationship."121 The statute then goes on to describe the scope of its coverage: " "Dating relationship' means a social relationship of a romantic nature. Factors that the court may consider m making this determination include: (a) [t]he length of time the relationship has existed; (b) the nature of the relationship; and (c) the frequency of interaction between the parties."122

Finally, West Virgimia's definition of "family or household members" mcludes "current or former sexual or intimate partners."123 These more inclusive definitions allow teens, and others in dating relationships, to take advantage of the reforms promulgated by domestic violence victim advocates, which will be discussed in Part V.

\section{Discrepancies Between Civil and Penal Definitions of Domestic Violence}

Apart from a state's civil code, which typically allows domestic violence victims to obtain restraining orders, ${ }^{124}$ and/or provides funding for viction services such as shelters, ${ }^{125}$ a state inay also have enacted domestic violence statutes in its crimmal or penal code. ${ }^{126}$ The result, in some states,

117. N.M. STAT. ANN. § 40-13-2(D) (amended 1993), available in WESTLAW, ST-ANN-ALL Database.

118. N.D. CENT. CODE § 14-07.1-01(4) (1991).

119. 23 Pa. Cons. Stat. Ann. \& 6102(a) (Supp. 1992).

120. No. 88-20, 817, Court of Common Pleas of Lycoming County, Pa., cited in Kuehl, supra note 6 , at 217 .

121. WASh. Rev. Code ANn. $\$ 26.50 .010$ (2) (West Supp. 1993).

122. Id. $\S 26.50 .010(3)$.

123. W. VA. CODE § 48-2A-2(b) (Supp. 1993).

124. See, e.g., Cal. Crv. Proc. Code $\$ 545.5$ (West Supp. 1993).

125. See, e.g., Irl. AnN. Stat. ch. 20, para. 2210/3 (Smith-Hurd 1993).

126. See, e.g., Cal. Penal Code $\$ 243$ (c) (West Supp. 1993); Minn. Stat. AnN. $\$ 629.341$ (West Supp. 1993); N.C. Gen. Stat. § 15A-534.1 (Supp. 1992); Ohio Rev. Code ANn. § 2919.25 (Anderson 
is two or more separate and even conflicting definitions of what constitutes domestic violence and of who qualifies as a domestic violence victim. ${ }^{127}$ This problem is averted in states where the donestic violence act is part of the criminal code ${ }^{128}$ or where the criminal domestic violence code relies on the definition set forth in the civil code. ${ }^{129}$ In states where the statutory definitions in the penal and civil codes differ, teenage daters may qualify for protection under the penal but not the civil code, or vice versa. ${ }^{130}$ The legislature must employ an integrated approach to combat these discrepancies so that when donestic violence definitions in civil codes, for example, are amended, the corresponding criminal codes are also amended.

\section{Conflicting Civil and Penal Definitions in States Where Teenagers Are Not Excluded from Domestic Violence Deflnitions}

Even in states where civil domestic violence statutes do not operate to exclude teenagers from their coverage, teen victims of intimate abuse may still be burdened by criminal legislation which excludes teens from its purview.

Pennsylvamia's civil and criminal codes provide a dramatic example of this lack of coordination. Pennsylvania's civil code includes teenage daters by defining domestic violence as abuse between sexual or intimate partners or coparents, ${ }^{131}$ whereas the penal code includes only spouses and current

1993); R.I. Gen. LAws § 12-29-2 (Supp. 1992); S.D. CodIFEd LAws ANn. §§ 23A-3-2.1 to -2.2 (Supp. 1993); WASH. Rev. Code Anv. § 10.31.100 (West 1990), as amended by S.B. No. 5107, Reg. Sess. (1993), reprinted in 1993 Wash. Legis. Serv. 444 (West).

Some of these penal codes make domestic violence a separate, specific criminal offense. See, e.g., Oho Rev. Code ANN. § 2919.25 (Anderson 1993). Others merely act as a mechanism to provide for stricter enforcement of current assault laws in the domestic violence context. See Developments in the Law, supra note 48, at 1529 n.5 (discussing both types of domestic violence penal provisions).

127. Ala. Code §§ 15-10-3(8) (Supp. 1993), 30-6-1 (1989); Cal. Crv. Proc. Code $\S 542$ (West Supp. 1993); CaL. Penal Code $§ \S 243,273.5$ (West Supp. 1993), 13700 (West 1992); Ill. AnN. Stat. ch. 20, para. 2210/1 (Smith-Hurd 1993), ch. 725, para. 5/112A-3 (Smith-Hurd Supp. 1993); MrcH. Comp. Laws Ann. $\S \S 400.1501$ (West 1988), 764.15a (West 1982); Minn. Stat. Ann. §§ 518B.01 subd. 2, 629.341 (West Supp. 1993); 18 PA. Cons. Stat. Ann. § 2711 (Supp. 1992); 23 id. § 6102 (Supp. 1992); R.I. GEN. LAws §§ 12-29-2 (Supp. 1992), 15-15-1 (1988); S.C. CodE ANN. §§ 16-25-10, 20-4-20 (Law. Co-op. 1985); S.D. CodifEd LAws ANN. §§ 23A-3-2.1 (Supp. 1993), 25-10-1 (1992); WASH. Rev. CoDE ANN. $\S \S 10.31 .100$ (West 1990), as amended by S.B. No. 5107, Reg. Sess. (1993), reprinted in 1993 Wash. Legis. Serv. 444 (West), 26.50.010 (West Supp. 1993).

128. Arz. Rev. Stat. Ann. § 13-3601 (Supp. 1993); Colo. Rev. Stat. § 18-6-800.3 (Supp. 1993); Mont. Code ANN. § 45-5-206 (1991); N.J. STar. ANn. § 2C:25-19 (West Supp. 1993).

129. See, e.g., Fla. Stat. Ann. § 901.15(7)(a) (West Supp. 1993); GA. Code AnN. § 17-4-20.1 (Harrison Supp. 1993).

130. Compare In. ANn. Star. ch. 20, para. 2210/1 (Smith-Hurd 1993) with id. at ch. 725, para. 5/ 112A-3 (Smith-Hurd Supp. 1993) (extending protection under the criminal code but not under the civil code to "persons who have or have had a dating or engagement relationship"); 18 PA. Cons. STAT. ANN. \& 2711 (Supp. 1992) with 23 id. \& 6102 (Supp. 1992) (extending protection under the civil code but not under the criminal code to "sexual or intimate partners"); WASH. REv. CODE ANN. § 10.31.100 (West 1990), as amended by S.B. No. 5107, Reg. Sess. (1993), reprinted in 1993 Wash. Legis. Serv. 444 (West) with id. $\$ 26.50 .010$ (West Supp. 1993) (extending protection under the civil code but not under the criminal code to persons 16 years of age or older who have or have had a dating relationship).

131. 23 Pa. Cons. Stat. Ann. § 6102 (Supp. 1992). 
or former cohabitants. ${ }^{132}$ Similarly, while Washington's civil code has been amended to protect teen daters who have reached the age of sixteen and coparents, ${ }^{133}$ the criminal code still requires victims of domestic violence to be at least eighteen and have no dating provision or coparent provision. ${ }^{134}$

\section{Conflicting Civil and Penal Definitions in States Where Teenagers Are Excluded from Domestic Violence Definitions}

Even in states where teens are generally excluded from the scope of domestic violence statutes by requirements of marriage, cohabitation, coparentage, or adulthood, teenage daters may not be protected equally by the civil and penal codes. For example, a state's criminal code may not extend domestic violence protection to coparents, even when the civil code does, thereby severely limiting the legal options available to teenage daters who have a child in common. ${ }^{135}$

Minnesota's civil and criminal codes provide an example of this type of anomaly. ${ }^{136}$ Minnesota's civil code protects spouses, former spouses, parents and children, persons related by blood, current and former cohabitants, and coparents. ${ }^{137}$ The criminal domestic violence provision applies only to spouses, former spouses, current cohabitants, and former cohabitants. ${ }^{138}$

Alabama provides an example of a state with a penal code that is more inclusive than its civil code: its penal code includes coparents ${ }^{139}$ but its civil code requires cohabitation. ${ }^{140}$ Alabama's civil Marital and Domestic Relations code defines domestic violence as abuse between "family members who reside together." ${ }^{141}$ However, Alabama's criminal procedure code defines domestic violence as abuse between spouses, former spouses, parents, children, and any other persons related by blood or marriage, coparents, or present or former household members. ${ }^{142}$ While Alabama's criminal code is certainly not inclusive enough to accommodate all teen daters, it at least protects a discrete mimority of teen daters-coparents and former cohabitants.

Where penal and civil codes are inconsistent regarding a majority requirement, the more restricted defimition can also hurt teen victims. For

132. 18 id. § 2711 .

133. WASH. Rev. CODE ANn. $\$ 26.50 .010$ (West Supp. 1993).

134. Id. § 10.31 .100 (West 1990), as amended by S.B. No. 5107, Reg. Sess. (1993), reprinted in 1993 Wash. Legis. Serv. 444 (West).

135. See, e.g., MnN. Stat. AnN. §§ 518B.01 subd. 2, 629.341 (West Supp. 1993).

136. Id.

137. Id. § 518B.01 subd. 2.

138. Id. $\S 629.341$.

139. AlA. CODE § 15-10-3(8) (Supp. 1993).

140. Id. § 30-6-1 (1989).

141. Id.

142. Id. § 15-10-3 (Supp. 1993). 
example, both Michigan's penal and civil codes define domestic violence victims as current or former spouses or current or former cohabitants. ${ }^{143}$ However, the civil code requires that cohabitants or former cohabitants be adults or emancipated minors involved or previously involved in a consenting sexual relationship. ${ }^{144}$ The penal code does not. ${ }^{145}$ Conversely, South Dakota and Rhode Island's criminal codes impose a requirement of majority ${ }^{146}$ while their civil codes do not. ${ }^{147}$

Where a state's legislation contains different definitions of what constitutes domestic violence and who qualifies as a domestic violence victim, teens are not provided the full scope of protection that adult victims are provided. Thus, any legal reform should seek to eradicate these discrepancies by amending all relevant definitions of domestic violence.

\section{Shortcomings of Current Alternative Legal Protections for Teenage Victims of Domestic Violence}

Where teens imvolved in dating violence are not mcluded in a state's statutory definition of domestic violence, teen victims generally cannot take advantage of the state's domestic violence laws. However, this does not mean that these teen victims of dating violence are entirely without legal protection. Teen abusers may still be guilty of assault, and teen victims may still obtain generic civil restraining orders against their abusive boyfriends. The problem with these generic civil and penal remedies, however, is that they do not encompass the myriad of additional legal protections contained in domestic violence legislation. ${ }^{148}$

Teenage victims of dating violence may also find legal protection in the form of antistalking laws and in broad judicial construction of a domestic violence statute's coverage. However, even these alternative forms of legal protection have limitations.

\section{Antistalking Laws}

In addition to domestic violence laws, recently enacted antistalking legislation provides another potential mechanism for curtailing persistent abusive, threatening, or intimidating conduct. ${ }^{149}$ Following Califorma's lead, thirty states have added antistalking laws to their books. ${ }^{150}$ These antistalking laws generally criminalize "stalking" and/or "liarassing" behav-

143. Mich. CoMp. LAWS ANN. $\S \S 400.1501$ (West 1988), 764.15a (West 1982).

144. Id. $\$ 400.1501$ (West 1988).

145. Id. \& 764.15a (West 1982).

146. R.I. Gen. Laws § 12-29-2 (Supp. 1992); S.D. Codified Laws ANn. § 23A-3-2.1 (Supp. 1993).

147. R.I. Gen. Laws § 15-15-1 (1988); S.D. Codified Laws ANN. § 25-10-1 (1992).

148. See infra Part V.

149. See Robert A. Guy, Jr., Note, The Nature and Constitutionality of Stalking Laws, 46 VAND. L. REv. 991, 992 n.7 (1993) (listing 31 states with stalking laws).

150. See Developments in the Law, supra note 48, at 1534 n.47. 
ior. ${ }^{151}$ Unlike domestic violence laws, antistalking statutes typically do not require any specific relationship between the parties and generally apply to all age groups. ${ }^{152}$

Despite their general applicability, antistalking laws are best utilized as a supplement to, rather than a substitute for, domestic violence laws. Where teenage daters are excluded from the coverage of domestic violence laws, antistalking laws will afford them some protection. However, the existence of antistalking laws does not justify the exclusion of teenagers from the scope of domestic violence laws. The reason for this is fourfold.

First, most antistalking laws are not prospective in their relief. In other words, only a few states specifically offer antistalking restraining orders. ${ }^{153}$ Even then, such antistalking restraining orders may be available only after a conviction for stalking. ${ }^{154}$ Thus, the inclusion of teenage daters in domestic violence definitional statutes is vital. Only then will teen daters be able to obtain domestic violence restraining orders, which provide protection without a prior determination of criminal guilt.

Second, under the rubric of "aggravated stalking," most antistalking laws impose higher penalties on stalkers who violate restraining orders. ${ }^{155}$ Hence, if it were made easier for teenagers to obtain restraining orders by way of mclusive domestic violence laws, then antistalking laws would afford them even greater protection. A teenager who merely has a generic civil restraining order may not be sufficiently protected by antistalking laws because some states will find aggravated stalking only if the order violated is a domestic violence restraining order. ${ }^{156}$

151. See, e.g., S.D. Codified Laws ANN. \& 22-19A-1 (Supp. 1993) (making it a misdemeanor to "willfully, maliciously, and repeatedly follow[] or harass[] another person").

152. See, e.g., Ala. CODE § 13A-6-90 (Supp. 1993); IDAHo CODE § 18-7905 (Supp. 1993); Ill. Ann. Stat. ch. 720, para. 5/12-7.3 (Smith-Hurd 1993); S.D. Codified Laws AnN. § 22-19A-1 (Supp. 1993); Utah Code ANN. \& 76-5-106.5 (Supp. 1993).

153. The following states' antistalking laws allow restraining orders: $\mathrm{GA}_{\mathrm{A}}$. CODE ANN. $\S 42-8-35.3$ (Harrison Supp. 1993); Mrch. Comp. Laws ANN. § 600.2950a (West Supp. 1993); WASH. Rev. Code ANN. § 9A.46.040 (West 1988); W. VA. Code § 61-2-9a(i) (Supp. 1993); Wyo. STAT. § 7-3-509 (Supp. 1993).

154. See, e.g., GA. CODE ANN. §42-8-35.3 (Harrison Supp. 1993); W. VA. CODE § 61-2-9a(i) (Supp. 1993).

155. Ala. Code § 13A-6-91 (Supp. 1993); Alaska Stat. § 11.41 .260 (1993); Colo. Rev. Stat. $\S 18-9-111(5)$ (Supp. 1993); Fla. Stat. Ann. § 784.048(4) (West Supp. 1993); Lll. Ann. Stat. eh. 720, para. 5/12-7.4 (Smith-Hurd 1993); IND. CodE ANN. § 35-45-10-5(b) (West Supp. 1993); KY. Rev. Stat. ANN. \$ 508.140 (Michie/Bobbs-Merrill Supp. 1992); LA. Rev. Stat. ANN. § 14:40.2(B) (West Supp. 1993); Neb. Rev. Stat. $\$ 28-311.03, .04$ (Supp. 1992) (requiring a temporary restraining order even for the first offense); N.C. Gen. Stat. § 14-277.3(b) (Supp. 1992); R.I. Gen. Laws § 11-59-3 (Supp. 1992); S.D. Codified Laws Ann. § 22-19A-2 (Supp. 1993); Tenn. Code Ann. § 39-17-315(2) (Supp. 1993); VA. Code ANn. § 18.2-60.3(B) (Michie Supp. 1993).

156. See, e.g., Alaska StAT. $\$ 11.41 .260$ (1993); VA. CODE ANN. § 18.2-60.3(B) (Michie Supp. 1993). 
Third, unlike domestic violence laws, antistalking laws often impose an explicit "imtent" requirement. ${ }^{157}$ In effect, these laws require proof that the stalker intends to inflict harm on the victim. ${ }^{158}$ Hence, boyfriends who act out of deluded love, rather than an intent to harm, may not be guilty of violating antistalking laws, even if they incessantly follow, telephone, and intimidate the victim. ${ }^{159}$

Fourth, utilizing antistalking laws as the exclusive protective mechanism for teenage daters may be a short-sighted endeavor. Not only are antistalking laws more limited in their scope than domestic violence laws, they are also subject to attack on constitutional grounds. ${ }^{160}$ The constitutionality of antistalking laws, in terms of overbreadth, due process, vagueness, and First Amendnient issues, has been called into question. ${ }^{161}$ Commentators further note that an antistalking law that passes constitutional muster cannot reach all types of obsessive behavior; in these situations, injunctions and restraining orders are indispensable. ${ }^{162}$

Antistalking laws demnonstrate that legislatures are aware of the dangers of obsessive and abusive behavior. Yet, due to their inherent limitations, antistalking laws most effectively serve to suppleinent, rather than supplant, domestic violence laws.

\section{Broad Judicial Construction of a Domestic Violence Statute's Coverage}

In states where teenagers are excluded from the definition of doniestic violence victims, a battered teen might nevertheless be included within the coverage of that state's doinestic violence legislation if a judge decides to broadly construe the relevant statute. A recent New Jersey case, Desiato $v$. $A b b o t t,{ }^{163}$ provides an example of broad judicial interpretation of statutory coverage.

New Jersey's legislation defines donuestic violence as abuse inflicted by an "adult or an emancipated minor" upon

a person protected under this act [including] any person who is 18 years of age or older or who is an eniancipated minor and who has been subjected to doniestic violence by a spouse, former spouse, or any other person who is a present or former household member, or a person with whom the victim has a child in common. ${ }^{164}$

157. See, e.g., Iowa Code Ann. \& 708.11(b) (West Supp. 1993); Md. Crim. Law Code Ann. $\S 121 B(a)(3)$ (1993); N.J. Stat. ANN. § 2C:12-10(a)(2) (West Supp. 1993); Utar Code ANn. § 76-5106.5 (Supp. 1993).

158. Guy, supra note 149 , at 1008 .

159. Id. at 1008-09.

160. Id. at $993,1010-21$.

161. Id.

162. See, e.g., id. at 1025.

163. 617 A.2d 678 (N.J. Super. Ct. Ch. Div. 1992).

164. N.J. StAT. ANN. § 2C:25-19(a), (d) (West Supp. 1993). 
The plaintiff in the case was a young woman who had obtained a temporary restraining order against her boyfriend under New Jersey's Prevention of Doinestic Violence Act. ${ }^{165}$ Her boyfriend sought dismissal of the order, claiming that since they had never been married, shared the same legal residence, or parented a child together, she did not meet the jurisdictional requirements of being an alleged victim under the Act. ${ }^{166}$

The court held that although they had never inarried or cohabitated, the parties were nevertheless "de facto 'household ineinbers." "167 However, the court inade clear that "inore than a casual dating relationship" is required. ${ }^{168} \mathrm{~A}$ "case by case determination" using the following considerations inust be inade:

the frequency of time the parties spend together in the context of one or more of the following criteria ....: (1) [c]onstancy of the relationship[;] (2) [o]ver-might stays at each other's residence[;] (3) [p]ersonalty iteins such as jewelry, clothing and personal grooming effects stored at each other's residences[;] (4) [s]hared property arrangeinents ... [;] (5) [f]amiliarity with each other's siblings and parents socially in dining and/or entertainment activities together . . . . ${ }^{169}$

Desiato reveals that the "household ineınber" requirement may not pose an overwhelming obstacle to dating couples who do not actually reside together. ${ }^{170}$ However, the case involved an adult dating couple, and since New Jersey defines domestic violence in a inanner that effectively excludes teens through a majority requirenient, teens in New Jersey cannot take direct advantage of the decision. ${ }^{171}$ The case is nonetheless significant because it illustrates the potential remedies available to domestic violence victims when statutory scheines are liberally construed. If judges in states without an explicit "adult" requirement were to interpret doinestic violence defimitions liberally, the "household inember" requirenient might not be such an inpediment to dating adolescents.

It is important to note, however, that Desiato's liberal reading of the Act was made possible only because the legislature failed to define "household member" with precision. "Although the Act does not define 'houselold ineinber,' a fortiori, it cannot mean to hold residency and cohabitation as a prerequisite."172 Such judicial liberalisin will certainly not be possible in the many states where household member is clearly defined as a spouse

165. Desiato, 617 A.2d at 679.

166. Id.

167. Id. at 681 .

168. Id. at 680 .

169. Id. at $680-81$. The court intended these factors to be used "by way of example and not limitation." Id. at 680 .

170. Id. at 681 .

171. N.J. Stat. ANN. \$ 2C:25-19(d) (West Supp. 1993).

172. Desiato, 617 A.2d at 680 . 
or cohabitant. Additionally, it is unwise to compensate for legislative inadequacy by relymg solely on liberal judicial construction. The key to comprehensive protection for teen victims of dating violence is legislative amendment.

\section{IV \\ LEGAL REFORM}

\section{A. Proposed Reform}

In order to address the needs of teen victims of dating violence, at a minimum, state legislatures should amend their civil and penal domestic violence statutes to include within the scope of their coverage persons of all ages in dating, courtship, and engagement relationships. A model statute would include the following definition:

"Intimate violence" is defined as abuse between family and household members, and between intimate partners. "Intimate partners" include persons of any age imvolved in a dating, courtship, or engagement relationship.

Such a model statute could then list the factors relevant to a determination of whether a "dating, courtship, or engagement relationship" exists. Such factors could include the duration of the relationship, the nature of the interaction between the parties, and the amount of time the two parties spend together.

While legislative amendment will not obliterate other obstacles inherent in a legal system that restricts the rights of minors, it will represent an important improvement, both symbolically and substantively, in the protection of teen victims of dating violence. Teen dating violence laws should be incorporated into the already established framework of domestic violence laws because this will enable teen victims to reap the benefits of the major advances made through the domestic violence laws of many states.

At the same time, including dating teens under the rubric of doinestic violence has important implications for the abuser and hence to society at large. Failing to include teens under the domestic violence rubric signals a failure to fully address and understand the problem and enables a self-perpetuating cycle of generational violence to continue. By failing to send the same message to abusive teens that the law sends to abusive husbands, the state confirms the teenage boy's misconceptions: "This is not the same thing as wife abuse; I have a right to do it."

Teen dating violence should be recognized as a crime akin to adult intimate abuse not simply because it is in the best interest of the victim but because it is a social imperative. If teen dating violence is not taken seriously by legislatures, police, and judges, the generational cycle of violence will continue: "Boys who abuse their girlfriends act out of jealousy and possessiveness stemming from extreme insecurity. Uncliecked, these boys 
may become adult abusers." ${ }^{\text {173 }}$ However, legal enforcement can make a difference:

"Once somebody finds that violence is the way to get what you want and feel powerful, it is hard to change unless you have some sense that there is something really wrong with it or you experience some sanctions like arrest .... A lot of kids ... say that getting caught made a difference." 174

\section{B. Objections to Including Teenage Dating Relationships in the Statutory Definition of Domestic Violence}

Opponents of expanding the definition of domestic violence will make a number of arguments. Topping the hist may be an assertion that teen dating violence either does not exist or is inherently different from adult intimate abuse. However, the research summarized in Part II clearly estabhishes that teen dating violence is a problem of the same magnitude as adult intimate violence. Teen dating violence is just as prevalent as marital abuse and stems from many of the same social and interpersonal dynamics of marital abuse. Admittedly, teen violence differs from adult violence in certain respects; for example, teens probably are not financially dependent on their abusers. However, many teenagers are just as dependent, if not more dependent, on their abusers both emotionally and socially. ${ }^{175}$ Moreover, teens are clearly im as much danger as are adult women. Consequently, teen batterers require the same social and legal condemnation as their adult counterparts.

Other objectors may argue that teens should not be grouped statutorily with adult women because they may require more specialized services due to their different psychological and legal needs. While this observation is accurate, it certainly does not justify denying teens the same baseline legal protections available to adult women. Once teens are protected by existing basic domestic violence statutes, teen advocates can then push for legislation that addresses teen-specific problems.

Some may argue that teens are too immature to be in serious relationships and that the law should not "condone" such activity by recognizing its incident hazards. Nevertheless, teenagers will continue to date, regardless of whether the law "recognizes" it. Adults who are morally opposed to early sexual or intimate activity are free to raise their children as they wish. When young women's lives are put in jeopardy, however, arguments of individualized morality must take a back seat to the implementation of legal protections.

173. Abcarian, supra note 66 , at E1.

174. Id. at E1, E14 (quoting Barrie Levy, therapist and founder of the Southern California Coalition for Battered Women) (second alteration in original).

175. See supra text accompanying note 52 . 
Another objection may stem from the fear that giving teens more legal rights may upset the authority structure in the family. However, teens are still minors and do not have standing on their own in civil cases. Accordingly, some adult, likely a parent, will be involved in the legal action from the start. While expanding domestic violence definitions to include dating teens will increase teens' legal options, it alone will not effectively auginent their legal power. The issue of parental consent and notification will be dealt with in more depth in Part VI.

Another objection could revolve around the perceived difficulty courts will encounter in attempting to determine what constitutes a "dating relationship." However, as explained in Part III.B, those states that have already included dating relationships in their domestic violence statutes have developed, either legislatively ${ }^{176}$ or judicially, ${ }^{177}$ a set of factors used to assess the legitimacy of a dating relationship. Regardless of which of the two approaches is taken, it is possible to define the term "dating relationship."

Another objection, annong the oldest, is a belief that "private" problems are best settled by the individuals themselves. Yet, virtually every legislature now recognizes that intimate violence is not a private inatter but a social plague. Doinestic violence and other laws now consistently aim to protect citizens regardless of the relationship between them-a marriage license is not a hitting license. The argument that intimate violence is a private matter is no longer a viable justificatiou for official inaction. Domestic violence laws should no longer be seen as an unwarranted interference with certain personal relationships but as public intervention into "a general social problem."178 That teens are younger and unmarried should not remove the abuse from the public's eye, nor should it provide a justification for the battering.

Finally, objectors inay contend that teens are already granted legal protection in the form of generic civil restraining orders and existing criminal laws. However, this observation ignores the fact that domestic violence legislation already goes beyond making wife abuse illegal; depending on the state, it also grants the victim additional rights and creates broader responsibilities for the police and judiciary. Thus, statutory inclusion will enable the teen victim to take advantage of the legal advances forwarded by domestic violence victim advocates. To contend that existing criminal and civil laws are enough to protect teen victims ignores the fact that doinestic violence laws developed precisely because existing laws did not adequately protect adult intimate violence victims. The legal advances in the area of

176. See supra text accompanying notes $107,112-13,121-22$.

177. See supra text accompanying notes 168-69.

178. Mary E. Asmus et al., Prosecuting Domestic Abuse Cases in Duluth: Developing Effective Prosecution Strategies from Understanding the Dynamics of Abusive Relationships, 15 HAMLINE L. REv. 115, 117 n.11 (1991). 
domestic violence legislation will be explored extensively in the following Part.

\section{$\mathrm{V}$ \\ What the Domestic Violence Movement Has ACCOMPLISHED}

Statutory inclusion will enable teen victims of intimate violence to take advantage of the legal victories that have resulted from the efforts of the domestic violence movement. Indeed, battered women's advocates have made great strides in developing and pushing legislation that takes battering seriously. Advocates have enabled shelters to get funding, have made restraining orders specifically under the rubric of donestic violence laws possible, and have sensitized judges and police officers to the need to enforce restraining orders.

Despite the fact that legal protection for abused women is currently inadequate, ${ }^{179}$ legal protections are nonetheless helpful in deterring some abuse and im instilling a feeling of powerfulness in the abused:

Legislation can empower the victin of domestic violence and let her know she doesn't have to deal with the violence all by herself; at the same time it sends a powerful message to the batterer: The state government knows what you are doing and it not only disapproves but will punish you as well. ${ }^{180}$

The legal system's response to battering has been greatly improved by certain reforms that are advantageous to adult women, reforms that could be of great assistance to teens as well. It should be noted, however, that although such reforms are not universal, the relevant statutes can serve as models for other states. Once again, the purpose of examining legislative reforms in detail is to expose the implications of exclusionary domestic violence definitions.

What follows is an exploration of various advances made in the legal protection of domestic violence victims. Almost without exception, these advances have the potential to protect teen victims as well.

\section{A. Legislative Reforms Involving Domestic Violence Restraining Orders \\ 1. Waiver of Filing Fees}

An unnecessary obstacle confronting teens, as well as adult women, is the filing fee required for restraining orders:

Since prosecution for violation of a criminal statute does not require filing fees, the fees should not be required for restraining orders either. A battered woman should not have to pay the court to obtain

179. See Waits, supra note 3, at 299 ("Full-scale, vigorous legal response to battering remains the exception and not the rulc.")

180. Kuehl, supra note 6, at 209-10. 
protection that is legally required by criminal statutes which are selectively enforced by the criminal justice system. ${ }^{181}$

Some state statutes provide for a waiving of the fee for domestic violence restraining orders upon a showing of indigence, ${ }^{182}$ while other statutes provide that no fee shall be assessed at all or until a judicial hearing. ${ }^{183}$ If teens are considered victims of domestic violence in these states, they can obtain domestic violence restraining orders even if they are unable to afford them. In states where teens are not deemed victims of domestic violence, they must file for generic civil restraining orders, which are not as likely to have such fee waiver provisions. ${ }^{184}$

In Nebraska and South Dakota, for example, there are provisions that prevent the court from considering the financial status of the abuser in assessing whether or not the applicant is indigent. ${ }^{185}$ This provision stems from an acknowledgment that abusers may have financial control over the abused, and hence, that the victim may have no independent access to the abuser's financial resources.

An analogous provision that considers the financial realities of the teen victim should be implemented. In assessing the indigence of teen victims, courts should be prohibited from considering the financial status of her parents since the battered teen may not have access to the funds.

\section{Clerk Assistance, Simplified Forms, and Guardians Ad Litem}

Some states have imstituted statutorily required clerk assistance in the filing process ${ }^{186}$ or have at least simplified the forms ${ }^{187}$ for domestic violence victims. Such provisions obviously provide imineasurable help to victims of interpersonal abuse whose self-confidence and personal initiative are severely hampered by the battering. However, the same legislature may not extend this rationale to persons filing for a generic civil restraining order and may not mandate assistance to persons who are not domestic violence victims as defined by statute.

181. Janice L. Grau, Comment, Restraining Order Legislation for Battered Women: A Reassessment, 16 U.S.F. L. REv. 703, 727 (1982).

182. See, e.g., Iowa Code Ann. § 236.3 (West 1985 \& Supp. 1993); LA. Rev. Stat. Ann. § 2138 (West Supp. 1993); MD. FAM. LAw Code ANN. § 4-504(c) (Supp. 1992); Neb. Rev. Stat. § 42-924.01 (Supp. 1992); N.M. Stat. AnN. \& 40-13-3(D) (Michie 1989); S.D. Codified Laws AnN. § 25-10-3(4) (1992).

183. See, e.g., ARK. Code Ann. § 9-15-202 (Michie 1991); Ky. Rev. Stat. Ann. § 403.730(3) (Michie/Bobbs-Merrill Supp. 1992); ME. Rev. Stat. ANN. tit. 19, § 764(3) (West 1981); N.H. Rev. Stat. ANN. § 173-B:3(II) (1990); VT. Stat. AnN. tit. 15, § 1103(c) (1989); W. VA. Code § 48-2A-4(f) (Supp. 1993).

184. See, e.g., Clerk of the Superior Court, Alameda County, California, Fee Schedule (Aug. 2, 1993) (imposing no filing fee for a domestic violence restraining order, while requiring a $\$ 182$ filing fee for a general civil restraining order).

185. Neb. Rev. Stat. § 42-924.01 (Supp. 1992); S.D. Codified Laws ANN. § 25-10-3(4) (1992).

186. See, e.g., Haw. Rev. Stat. § 586-3 (1985 \& Supp. 1992).

187. See, e.g., N.M. Stat. AnN. § 40-13-3(E) (Michie 1989). 
Thus, teens, whose self-esteem and motivation are equally bruised, may face a more difficult filing process if not allowed to obtain a domestic violence restraining order. Furthermore, because of their relative immaturity and inexperience with legal proceedings, teens who are denied assistance or simplified forms may perceive the process to be too cumbersome and may not seek the order as a result.

Many statutes already have a mechanism whereby the court appoints a guardian ad htem ${ }^{188}$ or allows an adult to file on behalf of a minor victim. ${ }^{189}$ These provisions were mainly intended to protect the interests of minor children affected by domestic violence in the context of custody disputes or child abuse. ${ }^{190}$ However, abused teens can only take advantage of the use and appointments of guardians ad litem in the domestic violence restraining order filing process if they are deemed "domestic violence victims."

Such provisions, absent more inclusive definitions, will not afford the teen any advantage since these provisions are found in the domestic violence restraiming order legislation and not necessarily in the generic civil restraining order legislation. Nonetheless, teens may still be able to obtain generic restraining orders via guardians ad litem, but the court may not be required to appoint one. Teens involved in dating relationships may have isolated themselves from their family and friends, or they may be too ashamed of the violence ${ }^{191}$ to find an adult who will file on their behalf. The importance of a court-appointed guardian ad litem to teen victims should not be underestimated. Therefore, states that already have guardian ad hitem appointment provisions should enact more inclusive domestic violence defimitions.

Similarly, states with statutes that have the more inclusive domestic violence defimitions that explicitly encompass dating relationships should adopt guardian ad litem appointment provisions since definitional inclusion itself does not eradicate all the obstacles that teens must face in the judicial arena. As minors, teens between the ages of thirteen and seventeen are demed standing to file on their own. Hence, the appointment of a guardian ad litem will enable teens to overcome a major roadblock to legal protection.

188. See, e.g., Alaska Stat. \$ 25.35.010(a) (1992).

189. See, e.g., Ga. Code AnN. § 19-13-3(a) (Harrison 1990); Kr. Rev. Stat. ANn. § 403.725(3) (Michie/Bobbs-Merrill Supp. 1992); ME. Rev. Stat. AnN. tit. 19, $\$ 764$ (1) (West Supp. 1992).

190. See, e.g., ME. Rev. Stat. ANN. tit. 19, \& 764(1) (West Supp. 1992) (allowing a person responsible for the child to seek relief on behalf of the child). Other statutes specify that the petition can be filed by "an adult family member ... on behalf of a minor family member." KY. REv. STAT. ANN. $\S 403.725$ (3) (Michie/Bobbs-Merrill Supp. 1992). The wording of the Kentucky statute seems to imply that the provision was meant to deal with the effects of intrafamily disputes on minor children. This notion is reinforced by the fact that Georgia, which has a similar provision, GA. CODE ANN. § 19-133(a) (Harrison 1990), also has a corollary provision that the court may order such temporary relief as necessary to protect the "minor of the household from violence." Id. § 19-13-3(b) (Harrison 1990).

191. Kuehl, supra note 6, at 212. 
A model statute is found in Alaska, which has both an inclusive domestic violence definition ${ }^{192}$ and an appointment provision: "The court may appoint a guardian ad litem or attorney to represent a minor who is subject to this chapter . . .."193 The combination of a domestic violence definition that includes dating relationships with the possibility of guardian ad litem appoimtment means that an abused teen will be able to avail herself of legal protection with fewer obstacles.

\section{Emergency Protective Orders}

One marked advantage that domestic violence restraining orders have over more generic civil restraining orders is the availability of emergency injunctions. For example, in Illinois, temporary emergency orders can be served without notice to the alleged offender. ${ }^{194}$ However, such emergency relief is predicated upon a showing of "immediate and present danger of abuse."195

Kentucky's protective order statute provides that "[w]hen the elected, appointed, or special judge of the district is absent from the district, otherwise unavailable, or unable to act, any Circuit Judge shall have the authority to issue an emergency protective order . . .."196 Teens, who now typically resort to generic civil restraining orders, may be denied the option of emergency relief because they are not specifically included in this code section.

\section{Broad Court Discretion in Formulating Orders}

Domestic violence restraining orders, as well as generic restraining orders, typically prohibit the respondent from abusing, threatening, or contacting the victim. ${ }^{197}$ Some restraining orders prescribe more protective commands, such as requiring the alleged abuser to stay away from the victim's residence or place of employment. ${ }^{198}$ While a generic civil restraining order may seem adequate on its face to protect abused teens, domestic violence restraining orders carry certain advantages, not only in enforcement but also in judicial formulation.

For instance, a domestic violence restraining order often gives the judge broad discretion in formulating the order, a provision which would be invaluable in accommodating the specific needs and vulnerabilities of teen

192. Alaska Stat. \& 25.35.200 (1992).

193. Id. $\$ 25.35 .010(\mathrm{a})$.

194. Ill. ANN. Stat. ch. 725, para. 5/111-8(c) (Smith-Hurd 1992).

195. Ill. ANn. Stat. ch. 725, para. 5/111-8(c) (Smith-Hurd 1992).

196. Ky. Rev. Stat. Ann. § 403.725(5) (Michie/Bobbs-Merrill Supp. 1992).

197. See, e.g., CAL. Civ. Code $\S 4359$ (a)(2) (West Supp. 1993) (enjoining a party from "contacting, molesting, attacking, striking, threatening, sexually assaulting, battering, or disturbing the peace of" the victim).

198. See, e.g., ILL. ANN. STat. ch. 725, para. 5/111-8(b) (Smith-Hurd 1992) (allowing the court to prohibit the abuser from entering the victim's "residence, school, or place of business"). 
victims. Alaska grants the judge such discretion: "If, at the hearing, the court finds that the petitioner has been subjected to domestic violence by the respondent, the court may issue any order it determines to be necessary for the protection of the health, safety, or welfare of the petitioner . ..."199

New Hampshire's laws contain a similar provision: "Upon a showing of abuse of the plaimtiff by a preponderance of the evidence, the court shall grant such relief as is necessary to bring about a cessation of the abuse ...."200 Such discretion is helpful in the context of teen violence because the court could potentially order the abuser to change schools. In fact, the New Hampshire domestic violence restraining order statute specifically states that the defendant may be enjoined from entering the plaintiff's school. ${ }^{201}$

\section{Orders to Pay Medical Expenses, Attorney's Fees, and Damages and Orders to Engage in Counseling}

Another advantage of domestic violence restraining orders is that some provide, as part of the injunction itself, that the abuser pay the victim's medical expenses, damages, lost wages, attorney's fees, and counseling expenses. ${ }^{202}$ This means that the victim is spared the time, expense, and aggravation of a civil suit to recover damages. This two-in-one order is especially helpful to teens, who may not be aware of the right to recover such damage awards or who may believe that the minor offender is unable to pay. Because the financial resources of a minor offender will often be inadequate, the obvious corollary to these orders is parental liability for such damages, which will be discussed in Part VI.D.

Some domestic violence restraining orders also direct the abuser to engage im batterer's counseling. ${ }^{203}$ Such a mandate is obviously of central importance im curtailing the generational cycle of violence.

\section{B. Legal Enforcement of Domestic Violence Restraining Orders}

\section{Criminalization of Domestic Violence Restraining Order Violations}

Many states still rely solely on civil contempt as the remedy for generic and domestic violence restraining order violations, ${ }^{204}$ a practice of

199. ALASKa Stat. \& 25.35.010(b) (1992).

200. N.H. Rev. StAT. ANN. \& 173-B:4(I) (1990).

201. Id. \& 173-B:4(1)(a)(3).

202. See, e.g., id. $\S 173-\mathrm{B}: 4(\mathrm{I})(\mathrm{b})(6)(1990)$ (allowing victim compensation for lost earnings, medical expenses, mjury losses, moving and shelter expenses, and attorney's fees).

203. See, e.g., Alaska Stat. $\$ 25.35 .010$ (b)(7) (1992) (providing that the court may order the abuser to engage in counseling that "propose[s] alternatives to aggression").

204. See, e.g., Ga. Code AnN. \& 19-13-6(a) (Harrison 1990); Iowa Code Ann. $\S 236.8$ (West Supp. 1993); Kan. Stat. Ann. $\S 60-909$ (1983); Kx. Rev. Stat. AnN. $§ 403.760$ (Michie/BobbsMerrill Supp. 1992); LA. Rev. Stat. AnN. § 2137(A) (West 1982); Wash. Rev. Code AnN. $\S 26.50 .120$ (West 1986); W. VA. CODE $\S 48-2 A-7$ (a) (Supp. 1993). 
questionable effectiveness. ${ }^{205}$ However, thirty-five states have enacted criminal penalties, including criminal contempt or misdemeanor charges, for violations of domestic violence restraining orders. ${ }^{206}$ Massachusetts, for example, explicitly warns, "that violations of orders issued hereunder are criminal in nature."207

A state may criminalize violations of domestic violence restraining orders and still retain the availability of civil contempt proceedings but make the remedies mutually exclusive. ${ }^{208}$ Other states have used criminalization as a way to give enforcement real teeth. North Dakota, for example, makes a domestic violence restraining order violation a Class $\mathrm{A}$ misdemeanor and also holds the violator in criminal contempt. ${ }^{209}$ Hawaii's domestic violence laws not only criminalize the first violation but also require mandatory incarceration for each subsequent violation-forty-eight hours for the second violation, and not less than thirty days for the third. ${ }^{210}$ Washington's criminal code provides that any violation of a domestic violence restraining order combined with assault or reckless endangerment is a felony. 211

Even states with only civil contempt penalties have made strides. Some states, while mainly relying on civil contempt proceedings as the primary legal deterrent in domestic violence situations, will criminalize certain violations. In Kansas, for example, the enjoined person may be charged with criminal trespass if he enters certain property in violation of the order. $^{212}$

\section{Arrest for Restraining Order Violations}

Most states allow for the immediate warrantless arrest of domestic violence restraining order violators at the officer's discretion. ${ }^{213}$ Some states

205. The victim is required to fill out more pleadings in order to obtain the contempt citation. This adds to the victim's frustration and prolongs the legal proceedings. Furthermore, "[b]ecause penalties for civil contempt lie within the judge's discretion, civil contempt rarely results in punitive action. More often, it results in a fine or a mere direction fron the court to the offender not to repeat the offense." Grau, supra note 181 , at 729 .

206. See, e.g., Fla. Stat. ANn. $\$ 741.31$ (West Supp. 1993) (misdemeanor); Haw. Rev. Stat. § 586-11 (Supp. 1992) (misdemeanor); Ky. REv. STAT. ANN. § 403.763(2) (Michie/Bobbs-Merrill Supp. 1992) (misdemeanor); MD. FAM. LAw. Code ANN. § 4-509(a) (Supp. 1992) (misdenieanor); Neb. Rev. STAT. \$ 42-924(3) (Supp. 1992) (misdemeanor); N.D. CENT. CODE § 14-07.1-06 (1991) (misdemeanor and criminal contempt); OHIO Rev. CODE ANN. \$ 2919.27(B) (Anderson 1993) (misdemeanor or felony depending on number of violations); S.D. CoDIFIEd LAws ANN. § 25-10-13 (1992) (misdemeanor); VA. CoDE ANN. § 16.1-253.2 (Michie Supp. 1993) (misdenieanor).

207. Mass. Gen. Laws ANn. ch. 209A, § 3A (West Supp. 1993).

208. See, e.g., Ky. Rev. Stat. Ann. $\$ 403.760(5)$ (Michie/Bobbs-Merrill Supp. 1992).

209. N.D. Cent. Code § 14-07.1-06 (1991).

210. Haw. Rev. Stat. § 586-11 (Supp. 1992).

211. Wash. Rev. CODE ANN. § 10.99.050(2) (West Supp. 1993).

212. Kan. Stat. ANn. § 60-3107(2) (Supp. 1992).

213. See, e.g., Ky. Rev. Stat. ANN. $\$ 403.715(3)$ (Michie/Bobbs-Merrill Supp. 1992); Vt. Stat. ANN. tit. 15, § 1108 (1989). 
go further and make such arrests mandatory ${ }^{214}$ in cases where the officer witnesses a violation of the domestic violence injunction or has probable cause to believe that a violation has occurred. ${ }^{215}$ These provisions, which may not apply to generic restraining order violations, are advantageous because they remove the onus of enforcenient from the victim, who otherwise would have to go to court and claim the order was violated. A teen who is denied the protection of her abuser's immediate arrest because she does not have a doniestic violence restraining order may interpret this official response as an unwillingness to take her seriously. Moreover, she may become disillusioned with authority and, as a result, not seek legal assistance in the future.

\section{Law Enforcement Officer Duties}

\section{Mandatory Arrest Policies}

The statutory requirements that govern the enforcenent of domestic violence laws before a victim has received a restraining order differ from state to state. States that provide for immediate arrest when donestic violence restraining orders are violated do not necessarily mandate arrest when an officer is merely called to the scene of abuse. Fourteen states and the District of Columbia have mandatory arrest laws in all domestic violence situations. $^{216}$

Most states make arrest discretionary. ${ }^{217}$ When the decision is left to officer discretion, the mcidence of arrest nuay be as low as three percent. ${ }^{218}$ When arrest is discretionary, the police officer often asks the victim if she would like to press charges. In other words, the state puts the onus of

214. See, e.g., Iowa CODE ANN. § 236.11 (West Supp. 1993); Neb. Rev. Stat. § 42-928 (Supp. 1992); N.M. Stat. AnN. § 40-13-6(c) (Michie 1989); N.C. Gen. Stat. § 50B-4(b) (1989); TenN. CodB ANN. § 36-3-611 (1991); Wash. Rev. CODE ANN. § 10.99.055 (West 1990).

215. See, e.g., Iowa Code ANn. \& 236.11 (West Supp. 1993); Ky. Rev. Stat. AnN. \$ 403.715(3) (Michie/Bobbs-Merrill Supp. 1992); Mass. GEN. Laws ANN. ch. 209A, § 6(7) (West Supp. 1993); Neb. Rev. Stat. § 42-928 (Supp. 1992); N.M. Stat. ANN. § 40-13-6(c) (Michie 1989); N.C. Gen. Stat. $\S 50 \mathrm{~B}-4(\mathrm{~b})$ (1989) (requiring the presentation of an order in addition to probable cause); TENN. CODE ANN. § 36-3-611 (1991).

216. Arz. Rev. Stat. Ann. § 13-3601(B) (Supp. 1993); Conn. Gen. Stat. Ann. § 46b-38b(a) (West Supp. 1993); D.C. Code ANN. § 16-1031(a) (Supp. 1993); Haw. Rev. Stat. § 709-906(4)(e) (Supp. 1992); Iowa Code ANN. § 236.12 (West 1985 \& Supp. 1993); LA. Rev. Stat. ANN. § 2140 (West Supp. 1993); ME. Rev. Stat. Ann. tit. 19, § 770(5) (West Supp. 1992); Mo. AnN. Stat. $\S 455.085$ (1) (Vemon Supp. 1993); Nev. Rev. Stat. Ann. § 171.137 (Michie 1992); Or. Rev. Stat. $\S 133.055(2)$ (1991); R.I. GEN. Laws § 12-29-3(B) (Supp. 1992); S.D. Codified LAws ANN. § 23A-32.1 (Supp. 1993); Utah Code AnN. §77-36-2(3) (Supp. 1993); Wash. Rev. Code AnN. $\S 10.99 .030$ (3)(a) (West 1990); Wis. Stat. ANN. $\$ 968.075(2)$ (West Supp. 1992).

Under these mandatory arrest statutes, a police officer is required to make an arrest when he has probable cause to believe that a domestic assault has occurred. Developments in the Law, supra note 48, at 1537.

217. But see Sue Ellen Schuerman, Note, Establishing a Tort Duty for Police Failure to Respond to Domestic Violence, 34 ARIZ. L. REv. 355, 359 (1992) (finding that some statcs have mandatory arrest laws).

218. Id. 
enforcement on the victim. Such an approach neglects not only the dynamics of an abusive relationship but also the theoretical underpinning of our criminal laws that a crime agamst any person is a crime against society. ${ }^{219}$

It should be noted, however, that mandatory arrest policies are controversial. Some commentators fear for the rights of the batterer, others for the safety of the victim. ${ }^{220}$ However, to the extent that various states have determined that mandatory arrest policies are beneficial and have enacted the appropriate legislation, such legislation should be equally applicable to teen victims.

Some may argue that a reason to exclude teen dating relationships from domestic violence legislation is that the police may have more difficulty identifying abuse between mimors and may wrongly arrest in cases where it is just a "typical adolescent spat." Bruises and broken bones are as visible on young women as they are on adult women, however. Besides, mandatory arrest requires a finding of probable cause. ${ }^{221}$ The officer will ultimately have to make a judgment call in the adult context; there is no reason to think he or she will be any less able, if educated about all forms of intimate abuse, to make the same judgment in the teen context.

Another important reason to include teens under the rubric of domestic violence, even in states where arrest is not mandatory, is that officers often have special duties in domestic abuse arrests that they do not have in other assault situations. Such duties involve taking whatever steps are necessary to insure the victim's safety, mcluding staying on the scene to protect the victim, helping the victim to obtain medical care, transporting the victim to a safe place or shelter, and informing the victim of her legal rights and of the location of shelters and victim services. ${ }^{222}$ If an officer is called to the scene of teenage dating abuse, and he fails to characterize it as "domestic violence," the teen victim may be denied this type of assistance.

219. See Waits, supra note 3, at 316 ("We . . cannot and should not rely on battered women to effectuate a policy of arrest. ... [I]t is primarily the legal system's job to deter criminals ....").

220. See Developments in the Law, supra note 48, at 1538-40 (discussing the costs that mandatory arrest laws have been accused of imposing on the victim and on the criminal justice system).

221. See supra text accompanying notes 215-17.

222. See, e.g., ALA. CODE $\S 30-60-9$ (1989) (stating that officers may advise on the availability of facilities); AL_ASKA STAT. \$ 18.65.520 (1992) (stating that an officer shall orally inform the victim of her rights and the services available to her); CAL. Penal Code $\$ 264.2$ (West Supp. 1993) (stating that the victim shall be provided with a "Victims of Domestic Violence" card); FLA. STAT. ANN. § 741.29(1) (West Supp. 1993) (stating that an officer may advise the victim of shelters and her legal rights and remedies); IowA CODE ANN. $§ 236.12$ (West 1985 \& Supp. 1993) (stating that an officer may stay on the scene, assist the victim in obtaining medical treatınent, and inform the victim of shelters and her legal rights); Nev. REv. STAT. ANN. \$ 171.1225 (Michie 1992) (stating that an officer may imform the victim of shelters and her legal rights and remedies, mcluding the availability of a court order); UTAH CODE ANN. § 30-6-8 (Supp. 1993) (stating that an officer may inform a victim of shelters and her legal rights and remedies, stay on the scene, and assist the victim in obtaining medical treatment). 


\section{Tort Liability for Failure to Arrest}

One advantage to mandatory arrest legislation is that it provides the victim with a potential tort remedy against police inaction. Tort suits have the potential to serve as a key tool im securing police compliance with mandatory arrest policies. ${ }^{223}$ If teen dating violence were to be included under the rubric of domestic violence in a state where arrest is mandated, such suits might effectively insure that police apply domestic violence laws without regard to age.

Failure to provide police protection to individual citizens typically cannot give rise to mumicipal liability absent a special duty. ${ }^{224}$ However, it has been held that mandatory arrest statutes in themselves can impose such a duty. ${ }^{225}$ In Donaldson v. City of Seattle, ${ }^{226}$ the Washington Court of Appeals held that "[i]f the legislation evidences a clear intent to identify a particular and circumscribed class of persons, such persons may bring an action in tort for violation of the statute."227 Suclı a tort duty is justified because it "furthers the express legislative intent of protecting battered spouses by providing an incentive to comply."228 The legislative intent in sucl situations is to redress an under-enforcement of the criminal laws. ${ }^{229}$ Duties imposed by this legislative intent fall not only on law enforcement officials but also on the courts.

\section{Duties of the Court}

\section{Prosecution Without the Victim's Compliance}

Although police action is necessary, it is often not sufficient. The courts also liave a duty to protect the victim of intimate violence. Presently, many prosecutors will not carry through on a teenage dating violence case if the teen victim refuses to testify in court. ${ }^{230}$ Adult women face grave difficulty in testifying against an abuser; this difficulty may be compounded by the age and relative immaturity of a teen victim. Furthermore, while many district attorney's offices liave services and witness programs to help adult battered women, juvenile courts do not have such progranns. ${ }^{231}$

223. See Schuerman, supra note 217, at 372-74 (arguing that courts are justified in imposing tort liability for police failure to comply with a mandatory arrest statute).

224. See DeShaney v. Winnebago County Dep't of Social Servs., 489 U.S. 189, 196-97 (1989) (holding that where there is no affirmative right to government aid, the government's failure to protect an imdividual against private violence does not violate due process).

225. See Nearing v. Weaver, 670 P.2d 137, $139-40$ (Or. 1983) (holding that official discretion and immunity do not preclude potential liability arising from mandatory arrest statutes).

226. 831 P.2d 1098, 1101 (Wash. Ct. App. 1992).

227. Id. at 1101 .

228. Schuerman, supra note 217 , at 373 .

229. Donaldson, 831 P.2d at 1101 (fmding that domestic violence legislation was designed "to better enforce the current laws").

230. See Kuehl, supra note 6 , at 215 .

231. Id. 
Teens, therefore, may receive no support from the court in combatting the pressure from peers, family, and the abuser himself, not to testify.

Realizing the unique dynamic of intimate violence situations, some legislatures lave imposed explicit guidelines regarding the court's powers and duties in adult domestic violence situations. For example, Utah's Code of Criminal Procedure provides: "Because of the serious nature of domestic violence, the court, in domestic violence actions: . . . (e) may not disımiss a charge mvolving domestic violence at the request of the victim unless it lias reasonable cause to believe that the disimissal would benefit the victim ...."232 Similarly, Rhode Island recognizes the control an abusive defendant can exert over the victim, and thus provides "[r]estrictions" upon the duties of the court in its Domestic Violence Prevention Act. ${ }^{233}$ In Rhode Island, under legislative mandate, the court "[s]hall inake clear to the defendant and victim that the prosecution of the dounestic violence action is determined by the prosecutor and not the victim."234

Florida's legislature has gone even further. It requires that "[e]ach state attorney ... develop special units or assign prosecutors to specialize in the prosecution of doinestic violence cases .... [T] [Tese prosecutors, specializing in domestic violence cases, and their support staff shall receive training in donestic violence issues."235 The legislature explicitly states its intent that "doinestic violence be treated as an illegal act rather than a private matter." 236 To achieve this intent, the law inandates that "the state attorney in each circuit adopt a pro-prosecution policy for acts of donestic violence . . . . The filing or nonfiling of criminal charges shall be determined by these specialized prosecutors over the objection of the victiun, if necessary."237

Such pro-prosecution policies have proven effective in the adult context. For instance, in Duluth, Minnesota, significant increases in conviction rates occurred after that city introduced more stringent judicial procedures. ${ }^{238}$

It should be noted that pro-prosecution policies are controversial. They have been criticized as having the potential to patronize and to revictimize the victim. ${ }^{239}$ The experience in Duluth, however, belies such a contention. Victions who were subpoenaed as hostile witnesses to testify against their partners were subsequently interviewed, and a majority "said they were relieved when they were told that they could not have the charges

232. Utah Code ANN. \& 77-36-3(1)(e) (Supp. 1993).

233. R.I. GEN. LAwS $\S 12-29-4$ (Supp. 1992).

234. Id. § $12-29-4(\mathrm{~B})(4)$.

235. Fla. Stat. Ann. \& 741.2901(1) (West Supp. 1993).

236. Id. § 741.2901(2).

237. Id.

238. Asmus et. al., supra note 178 , at 136.

239. See Developments in the Law, supra note 48, at 1541 (discussing the "drawbacks" of proprosecution policies). 
dropped, even though they never would have voluntarily testified."240 In any case, despite the controversy, various states have determined that proprosecution pohicies are beneficial and have enacted legislation to implement such policies. In these states, such legislation should be equally applicable to teen victims.

\section{No Contact Orders}

Some courts may be authorized by statute to order a domestic violence law offender, as a condition of pretrial release, not to contact the victim or subject her to any more abuse. ${ }^{241}$ These "no contact orders" function as temporary restraining orders yet do not require any action on the part of the victim.

Advances such as the "no contact order" demonstrate the growing legislative awareness of the realities of intimate abuse. As the Utah legislature reminds the court:

Because of the likelihood of repeated violence directed at those who have been victims of domestic violence in the past, when any defendant charged with a crime involving domestic violence is released from custody before trial, the court authorizing the release may issue an order prohibiting the defendant from having any contact with the victim. ${ }^{242}$

Because these "no contact orders" arise only in the context of domestic violence offenses, courts will order such relief in the teen dating context only after teens are considered domestic violence victims.

\section{E. Shelter and Domestic Violence Services}

Many states have also created domestic violence funds to finance various services to assist abuse victims, but abused teens usually cannot benefit from these services. Such services include shelters, safe houses, support groups, education, counseling, programs to aid in the prevention and elimination of violence, and legal assistance. ${ }^{243}$ The statutes usually authorize distribution of money to help victims of domestic violence. ${ }^{244}$ However, as Part III pointed out, teens abused by their boyfriends rarely qualify statutorily as "victims of domestic violence."

This does not mean that shelters and organizations that are pubhicly funded can never help teen victims; however, certain statutes require that

240. Id. at 137.

241. See, e.g., Alaska Stat. § 12.30.025(a)(3) (Supp. 1992); N.J. Stat. AnN. § 2C:25-26(a) (West Supp. 1993); N.C. Gen. Stat. § 15A-534.1(2) (Supp. 1992); R.I. GeN. Laws § 12-29.4 (Supp. 1992); S.D. Codified Laws ANN. § 25-10-25 (1992); UtaH Code ANn. § 77-36-3(2)(a) (Supp. 1993); WASH. REv. CODE ANN. § 10.99.045(5) (West 1990).

242. UTAH Code ANN. § 77-36-3(2)(a) (Supp. 1993).

243. See, e.g., Neb. Rev. Stat. $\S \S 42-905$ (Supp. 1992), 42-907(4), (5), (7) (1988).

244. See, e.g., Conn. Gen. Stat. AnN. § 17-580(a)(3) (West 1992). 
they must ${ }^{245}$ help victims as statutorily defined. Thus, if funding is low or space is running out, which is typically the case, ${ }^{246}$ teens may be left out. Further, there are im fact statutes that do not permit teen assistance or severely restrict it. Oklahoma, for example, allows service to minor domestic abuse victims, but the minor victim must be a mother. ${ }^{247}$ Moreover, the statute specifies that "[s]uch shelter or care shall not extend beyond thirty (30) days unless the facility receives an order issued by the court to continue such services or the parent or guardian of the minor mother consents to such services."248

Other examples of implicit teen exclusion from shelters abound. For a shelter to receive a contract bid in Texas, "a public or private nonprofit organization must operate a family violence shelter center that provides temporary lodging and social services for adults and their children ...."249 Indiana law explicitly provides for emergency services, such as emergency shelters, a 24-hour telephone system to provide crisis assistance, emergency transportation, and information, referral, and victim advocacy services, to be made available to spouses or former spouses who are victims of domestic violence. 250

Illinois provides a recent exanple of enlightened change. Originally, the shelters were licensed to serve minors only if they were wards of the state. ${ }^{251}$ The state rewrote its licensmg requirements for shelters to accommodate abused teens. ${ }^{252}$ This change allowed for the opening of a battered women's shelter in Chicago, which planned to start special programs for teen parents and teen victims of dating violence. ${ }^{253}$

In addition to the exclusion of teen victims from shelters, most community and judicial services also neglect the need for preventive interventionist programs directed at young batterers. ${ }^{254}$ However, the District of Columbia Superior Court, recognizing that teen dating violence is a growing reality, has initiated a court-ordered treatment program to deal specifically with boys thirteen to eighteen years old as a counterpart to the

245. See, e.g., IND. CODE ANN. § 12-18-4-10(1) (West Supp. 1993) (extending shelter to spouses, former spouses, and dependent children).

246. See, e.g., Asmus et al., supra note 178, at 125 n.50 (noting that a Minnesota Department of Corrections report indicated that 5200 women, comprising about $65 \%$ of all women seeking shelter in Minnesota, had been turned down by state-funded shelters because of lack of space).

247. OKLa. Stat. AnN. tit. 43A, § 3-313a (West 1990).

248. Id. tit. $43 \mathrm{~A}, \S 3-313 \mathrm{a}(\mathrm{B})$.

249. Tex. Hum. Res. Code ANn. $\$$ 51.004(a) (West 1990).

250. IND. CODE ANN. § 12-18-4-10 (West Supp. 1993). In addition to spouses or former spouses, children of domestic violence victims can also receive shelter and couuseling. Id. § 12-18-4-10(1), (4).

251. Paula Kamen, Teen Victims: Little Being Done About Rampant Violence, Researcher Claims, CHI. TRIB., Nov. $3,1991, \S 6$, at 5 .

252. Id.

253. Id.

254. See Gamache, supra note 1 , at 82 (asserting that most communities, in their attempts to prevent intimate violence, fail to target young people). 
program already in place for adult batterers. "The need was clearly thereoffenders were coming in that were younger and younger."255

Although these examples demonstrate that changes targeted specifically at teens are possible, these instances are rare. Including teenagers in the coverage of doinestic violence legislation would still be useful in improving access to general domestic violence services for teen victims.

$$
\text { * * * }
$$

The legal systein has inade significant and substantial inroads in responding to the special needs of adult abuse victims. Since the dynamics of interpersonal abuse are largely independent of age, ${ }^{256}$ any systemic approach to intimate violence inust also coinbat abuse that begins before adulthood. Amending dornestic violence legislation to cover teen victiıns as well as adults would constitute an inportant step in that direction.

If that step were taken, however, certain special issues would be raised by the minority status of teens. These issues are addressed in the following Part.

\section{VI}

\section{SPECIAl IsSUES RaISED By the Minority Status of TEENAGERS}

\section{A. Police, Judicial, and High School Administrator Education}

Authorities who deal with adolescents are often insensitive to the needs of teen victims of domestic violence. "If an adult wornan says, 'Soinebody beat me up,' she is going to get a different response 9 times out of 10 [than] if a 15-year old says, 'My boyfriend beat ine up.' That's true [about] telling pohce, telling people at school, that's true with authority in general."257 Authorities, such as high school counselors and police, may not believe the victim or may not want to get involved. Nevertheless, although young woinen are seen as lacking credibility and fabricating stories of abuse, in fact, teen dating violence is severely underreported. ${ }^{258}$

If a teen turns to the police for help, she inay not be taken seriously. ${ }^{259}$ While inany states require police education about domestic violence, ${ }^{260}$

255. Shen, supra note 10, at A16 (quoting Desiree Dansan, acting supervisor of the D.C. Superior Court's domestic violence treatment program).

256. See supra Part I.A-B.

257. Kamen, supra note 251, at 5 (quoting Barrie Levy) (alteration in original).

258. Kuehl, supra note 6 , at 213.

259. See Levy, supra note 18, at 5 ("[P]olice may respond to [adolescents'] calls for help by saying, "they are just kids." ").

260. See, e.g., Alaska Stat. \& 18.65 .510 (1992); ARK. Code AnN. § 20-82-202 (Michie 1991); Cal. Penal Code $\$ 13519$ (West 1992); Fla. Stat. AnN. $\$ 943.171$ (West 1985 \& Supp. 1993); Iowa Code Ann. § 236.17 (West Supp. 1993); Me. Rev. Srat. Ann. tit. 19, § 770 (West 198I \& Supp. 1992); Mass. Gen. Laws AnN. cb. 6, § 116A (West Supp. 1993); Neb. Rev. Stat. § $42-927$ (1988); N.J. Stat. AnN. \& 2C:25-20 (West Supp. 1993); N.D. Cent. Code § 14-07.1-14 (1991); R.I. Gen. LAws § 12-29-6 (Supp. 1992); Tex. Gov't Code ANN. § 22.011 (West Supp. 1993). 
those programs typically do not explicitly address teen issues. Police training now includes teaching officers their legal duties in donestic violence situations; techniques for liandling incidents of domestic violence that promote the safety of the victim and reduce the likelihood of recurrence; the legal rights of victims; and how to provide einergency assistance to victims, including transporting victims to a hospital or shelter. The prevalence and special characteristics of teen dating violence would not be an onerous addition to the agendas of domestic violence training prograns.

Teens who are reluctant to deal with the police inay instead turn to their school officials for help. Unfortunately, though, school officials may not be any more helpful than the police: "School officials sometimes ignore the relationship violence in their midst or perceive it as isolated incidents instead of what may be an escalating pattern."261 Shockingly, there are reports that a principal who saw a boyfriend knock down and repeatedly punch his girlfriend, leaving her bruised and hini unscathed, suspended them both, because he viewed it as "two kids fighting."262 These types of official responses may merely reinforce the notion that the girl is equally to blame and teach her that she is living in a system unwilling to get involved. School officials need to be sensitized to the dynamics of intimate violence and need to be versed in the availability of legal remedies and community services.

Judges are also not immune to the stereotypical beliefs about intimate violence. ${ }^{263}$ Accordingly, judicial education is equally important and is in fact a requirentent in some states. ${ }^{264}$ However, once again, these educational courses typically refer to domestic violence as a problem of adult abuse. ${ }^{265}$ All judges and prosecutors should be informed that intimate violence is not limited to inarried couples and that teenagers are equally vulnerable and in need of judicial sensitivity. Since teen dating violence occurs between minors, special efforts slould be made to educate the officers of the juvenile courts. 266

Furthermore, juvenile court proceedings are informal relative to adult criminal proceedings, and the juvenile court judge inay attempt to help the

261. Abcarian, supra note 66 , at E14.

262. English, supra note 46 , at 15.

263. See Matthew Litsky, Note, Explaining the Legal System's Inadequate Response to the Abuse of Women: A Lack of Coordination, 8 N.Y.L. ScH. J. HuM. RTS. 149, 170 (1990) ("It is not uncommon for a woman ... to face a judge who may be predisposed against the use of the courts in family disputes.").

264. See, e.g., Fla. Stat. Ann. § 25.385 (West Supp. 1993); Ga. Code AnN. § 19-13-34(5) (Harrison Supp. 1993); N.J. Stat. ANN. \& 2C:25-20 (West Supp. 1993).

265. See, e.g., Fla. Stat. AnN. \$ 943.171 (West 1985 \& Supp. 1993) (defining "domestic violence" to mean "any assault, battery, sexual assault, sexual battery, or any criminal offense resulting in the physical injury or death of one family or household member by another who is or was residing in the same single dwelling unit").

266. Juvenile courts have jurisdiction over criminal matters where a minor is accused. Kuehl, supra note 6 , at 210 . However, a variety of state civil courts hear domestic violence restraining order cases. Id. Therefore, there is a need for judicial education in both settings. 
minor defendant by means of alternative sentencing rather than juvenile detention. ${ }^{267}$ While juvenile court judges should retain such discretion, they should also be encouraged to treat the offense as a "real" crime. Victims often report that the juvemile judges do not take them seriously; some judges merely advise the teen to stop dating the boy. ${ }^{268}$

Police, judges, and high school authorities should be educated so that they can recognize the problem of teen dating violence and begin to deal with it effectively.

\section{B. Teenage Education}

Unfortunately, the authorities are not alone in their misperceptions regarding teen dating violence. While strides have been made towards increased pubhic awareness of domestic violence, little has been done to educate teens themselves about intimate abuse among those in their age group. As a result of their relative immaturity and inexperience with intimate and sexual relationships, teens may have difficulty defining abuse as a problem that needs to be addressed. ${ }^{269}$ Even worse, they may accept it as normal: "A group of teen-age girls said they thought it was OK for their boyfriends to tell them what to wear. If the girls didn't comply, their boyfriends had a right to hit them, the young women said."270 It is estimated that only one out of every twenty-five teenagers in an abusive relationship will seek help. ${ }^{271}$ Education, therefore, is crucial.

Even a victim of teen battering who has identified the abuse as a problem may not be aware that it is a crime. And even if she is aware of her legal rights, she still probably has no idea how to access them. Furthermore, she may be discouraged from doing so. Many friends and family members she confronts with the problem will "reflect the underlying sexism of a society that blames the fenuale victim and excuses the male criminal, simply because there is a relationship between the two."272 Intimate violence awareness classes or seminars are necessary additions to school curricula.

Such education would also be imperative for young males so that they can learn what forms of behavior are appropriate. Counselors who have worked with male teens cite the boys' frightening misconceptions about sex and relationships: "One tecn-age boy told a counselor that if he put his hand on a girl's knee and she left it there, that meant she wanted to have sex."273

267. Id. at 211 .

268. Id. at 211.

269. Levy, supra note 18, at 5; see also supra text accompanying notes 32-34.

270. Limda Goldston, Date Rape Crisis: A Desperate Need for Education, SAN Jose MrRcurY News, Aug. 6, 1991, at 1A.

271. Roan, supra note 33, at E5.

272. Kuehl, supra note 6, at 212-13.

273. Goldston, supra note 270 , at 1A. 
Until recently, however, "school officials largely ignored the problem, in part because they feared it would require frank discussions of sex and violence that might offend conservative parents." ${ }^{\text {"274 }}$ Soine states, however, have recently tackled the problen head on. Minnesota has initiated a dating violence prevention program that is a mandatory part of the statewide curriculum. ${ }^{275}$

Nebraska has also realized the importance of early education. A section of its Protection from Doinestic Abuse Act calls for the development "in cooperation with the State Department of Education, [of] a kindergarten through postsecondary educational curriculum relating to doinestic violence."276 Soine inay object to the curriculum being introduced as early as kindergarten, claiming the children are too young to hear about intimate and/or sexual relationships or that the appropriate place for such learning is in the home. Yet, kindergarten is not too early because, according to some reports, abusive patterns are surfacing in elementary age children. ${ }^{277}$ Furthermore, the evidence of distorted teen attitudes regarding violence in relationships reveals that education at hoine has yet to serve as an entirely effective device in countering teen abuse.

Unfortunately, school programs may be the first to go in difficult financial times. In California, for example, violence awareness programs ained at all age levels were under way at most schools in the state until former Governor Deukmejian, entangled in a budget crisis, cut money froin the Child Assault Prevention programs. ${ }^{278}$

\section{Parental Consent and Notification}

If abused teens' legal options are expanded, the next question is what becomes of the parental role in this context. Unless emancipated, teens seeking restraining orders inust have a guardian ad litem. ${ }^{279}$ However, that gnardian need not be a parent. Thus, it does not appear that parental consent is a prerequisite to obtaining legal assistance in the form of restraining orders. However, if teens are allowed access to domestic violence legislation via more expansive and explicit definitions of intimate violence, parents inay deinand a role in the process. Emphasizing the need to respect the integrity of the family unit, parents may demand that their consent be required before judicial action is taken or that they may at least ask for notification of it.

274. Shen, supra note 10, at A16.

275. Id.

276. Neb. Rev. Stat. § 42-914 (1988).

277. Goldston, supra note 270 , at 9 A ("A problem we've had is with elementary schools, where groups of boys circle young girls and sexually batter them ...." (quoting Diane Santellan, Crisis Intervention Coordinator, Bay Area Women Against Rape, Berkeley, California)).

278. Id.

279. Kuehl, supra note 6, at 211. 
The abortion debate has fueled the controversy concerning the proper allocation of rights between parents, the state, and children. However, the arguments forwarded in the abortion context for parental consent and/or notification do not hold up in the case of battering. In the abortion context, the rationales typically proffered as to why a minor's right to abortion should be regulated more than an adult's include: a minor is typically vulnerable; a minor may be unable to make critical decisions with sufficient information and maturity; ${ }^{280}$ and a parent should play the important role in child rearing. ${ }^{281}$

The argument that a legally empowered teen will act against her best interest is an untenable justification for requiring parental consent to a minor's application for a protective order. In the context of battering, there is little danger that in seeking a restraining order or other legal assistance the iminature teen will make an impulsive choice contrary to her social and moral interests. Granted, some may fear that certain teens, because of their immaturity, will abuse the process by making trivial and unwarranted claims against their boyfriends. However, judges appear to be in the best position to sort the legitimate claims from the fabricated ones. Indeed, parental notice statutes in the abortion context are constitutionally valid if there is the option of judicial bypass ${ }^{282}$ safeguarding the teen from her own iminaturity and from her family. This judicial safeguard is inherent in the domestic violence setting since a judge must issue protective and other court orders.

However, the law acknowledges that a minor is not completely autonomous. The legal systen grants parents the primary child rearing role because it assumes that parents' love for their child will foster decisions that are in the best interest of the child. ${ }^{283}$ Also, "policies favoring family autonomy may reflect a lack of confidence in governmental wisdom: we may allow families to make poor decisions for fear that governmental decisions would often be even worse."284 Some feel the issue is not about who is in the best position to make decisions but who inherently has the right to make such decisions. The Supreme Court has indicated that the Constitution grants parents wide latitude in deciding how to raise their children and that a parent has a constitutional right to be free from "undue,

280. Sue G. Graziano, Parental Notification and a Minor's Right to an Abortion after Hodgson \& Akron II, 17 Orio N.U. L. Rev. 581, 582 (1991) (discussing the Suprcme Court's rationale in Bellotti v. Baird, 443 U.S. 622 (1979)).

281. Id.

282. See id. at 597 ("What is clear from the Akron II and Hodgson holdings is that state legislatures may enact parental notice statutes with a judicial bypass.").

283. Waits, supra note 3, at 299-300.

284. Id. at 300. 
adverse interference by the State."285 At the same time, however, children have a right to be free from bodily abuse. ${ }^{286}$

The state's interest in protecting the life of the battered teen outweighs the state's interest in mamtaining the integrity of the family unit. In the perfect family setting, a teen would seek advice and help from her parents. In reality, however, there may be a variety of reasons why an abused teen may not want to confront her parents. These range from a fear that she will not be believed, to feelings of shame and responsibility, to a fear that her parents will blame her and restrict her future freedom. Additionally, the trust and closeness that facilitate open communication may be absent.

Proponents of consent and/or notification requirements may fear that giving the teen legal power will cause a rift in family relations and interfere with the authority structure of the family. This argument imverts cause and effect. Frequently, the reason a teen does not want to consult her parents is because familial relations are already strained. ${ }^{287}$ Forcing a teen to confront her parents will not be a panacea for the family's disharmony; it will just mean that many abused teens will not take advantage of the legal system. A teen's safety and emotional well-being should not be the price society pays to promote family values. The law has an interest in protecting the family unit, but it has a stronger interest in protecting individual family members.

The parent's imterest in child rearing is an important factor to be considered. It is not the only one, however. Where a victim is in danger, her self-determination must be respected. Therefore, in the context of protection of abused teens, parental consent should not be required.

\section{Parental Tort Liability}

Affording the teenaged victim protections against the batterer is not enough. When the batterer is a minor, the victim should be able to recover medical expenses and tort damages from the abuser's parents if the abuser cannot compensate the victim himself. Every state has some form of parental liability statute which imposes a duty on parents to pay for the injuries caused by the intentional torts of their children. ${ }^{288}$ The injured, in most states, must prove that the minor child committed a willfnl or malicious tort, and the amount of recovery may have a cap. ${ }^{289}$ Caps range from a low of $\$ 250$ in Vermont to a high of $\$ 15,000$ in Texas. ${ }^{290}$ Hawaii, Louisiana,

285. Bellotti v. Baird, 443 U.S. 622,639 n.18 (1979).

286. See Ingraham v. Wright, 430 U.S. 651, 672-74 (1977) (corporal punishment in schools implicates Fourteenth Amendment liberty interest).

287. See Levy, supra note 18 , at 5 .

288. Frank E. Harper, To Kill the Messenger: The Deflection of Responsibility Through Scapegoating (A Socio-Legal Analysis of Parental Responsibility Laws and the Urban Gang Family), 8 HARv. BL.ACKLETTER J. 41, 42-43 (1991).

289. Id. at 43 .

290. Randall K. Hanson, Parental Liability, 62 Wis. LAw., Sept. 1989, at 24, 25. 
and New Jersey have not set maximum recovery limits. ${ }^{291}$ Unfortunately, in twenty states, parents are only liable for property damage and not personal injuries caused by their children. ${ }^{292}$ Even the thirty states that allow recovery for personal imjury have relatively low caps, which seems to imply that the purpose of parental liability is to discourage delinquency rather than to compensate the victim. ${ }^{293}$

Liability is justified because our justice system assumes that parents are in some way responsible for the acts of their children: "Parental responsibility laws are grounded in the notion that parents have some level of control over, and therefore, responsibility for their children's deviant behavior."294 Yet, parents are held liable even if there is no evidence that they failed to use reasonable care. Critics may label this vicarious liability unfair in the abstract since the parents themselves have not breached any duty towards the victim. Furthermore, critics may argue that seeking to give teen girls more legal rights is hypocritical unless it also gives teen boys more liabilities. Since there is credence to this argument, parental tort liability should be premised on the issue of fairness rather than responsibility.

Equitable considerations mandate that since the victim is blameless, she should not be burdened with expenses resulting from the abuse. Therefore, if the minor abuser is able to pay, he should be held principally liable. However, if the minor abuser is without an income, a normative decision concerming fairness must be made. Either the victim or her parents will pay, the victim will forgo needed medical treatment, counseling, tutoring, and replacement of clothing, or the abuser's parents will pay. Mandating that the abuser's parents cover medical and tort hability is the most reasonable solution, but it is one that will require legal changes in many jurisdictions.

\section{ConCLusion}

Since the epidemic of teenage dating violence has been exposed, society now has both a duty to respond and an interest in responding. Intimate violence is no longer considered a private matter but a public plague that must be combatted with stringent enforcement of enlightened laws. While the law has made strides to protect adult victims, little has been done to alleviate the situation of teen abuse. The law must accord teen women the same protection available to adults. Teen men must be taught early that violence is not an acceptable way to handle difficulties. The law is not a panacea - society's attitudes towards women and intimate relationships in general must be overhauled. But the law is a start: "[D]o nothing arguments ignore the symbolic value of the law-that the law can lead as well

291. Id.

292. Id. at 25-26.

293. Id. at 26.

294. Harper, supra note 288 , at 54 . 
as follow."295 Unless we formulate a coherent communal and legal response to the epidemic of teenage dating violence, the generational cycle of violence will continue.

295. Waits, supra note 3 , at 301 . 
